\title{
Improvements on the back-calculation technique for estimating anthropogenic $\mathrm{CO}_{2}$.
}

Fiz F. PÉREZ*, Marta ÁLVAREZ and Aida F. RÍOS

Instituto de Investigaciones Marinas, CSIC, Eduardo Cabello, Nº6, 36208 Vigo, Spain.

* Corresponding author, email: fizfperez@,iim.csic.es

Fax: +34 986292762

Phone: +34 986231930360

To appear in: Deep-Sea Research I

Version: 5-Dec-2001

Running head: Improvements on the back-calculation technique. 


\begin{abstract}
.
The back-calculation technique for evaluating the anthropogenic $\mathrm{CO}_{2}\left(\mathrm{C}_{\mathrm{ANT}}\right)$ input corrects total inorganic carbon for the remineralization of organic matter and the dissolution of calcium carbonate, along with subtracting the pre-industrial equilibrium total inorganic carbon. This technique is mainly dependent on the estimation of the preformed values of total alkalinity, oxygen and partial pressure of $\mathrm{CO}_{2}\left(\mathrm{pCO}_{2}\right)$. A new approach for estimating the preformed alkalinity $\left(\mathrm{TA}^{0}\right)$ in the North Atlantic Ocean is suggested. $\mathrm{TA}^{0}$ is parameterized as a function of the inorganic to organic carbon decomposition ratio in the water column in agreement with sediment trap data and a recent review by Milliman et al. (Deep-Sea Research I, 46, 1653-1669, 1999), which gives evidence for a considerable calcium carbonate dissolution in the upper 500-1000 m of the ocean, above the lysocline. We recalculated the $\mathrm{C}_{\mathrm{ANT}}$ content in a section along the Eastern North Atlantic (OacesNAtlIIB-93) using this new $\mathrm{TA}^{0}$, the Mehrbach et al. (Limnology and Oceanography, 8, 897-907, 1973) $\mathrm{CO}_{2}$ dissociation constants, and including the effect of water vapor pressure on estimation of the pre-industrial $\mathrm{pCO}_{2}$. Our findings lead us to conclude that the $\mathrm{CO}_{2}$ disequilibrium when water masses are formed is small and not significant. Direct and indirect evidence based on available high-quality $\mathrm{CO}_{2}$ data taken in formation areas in late winter conditions support this argument.
\end{abstract}

Keywords: Anthropogenic Carbon, Preformed Alkalinity, North Atlantic Ocean, $\mathrm{CO}_{2}$ Disequilibrium.

\title{
1. INTRODUCTION.
}

The oceans have taken up from one third to one half of the anthropogenic $\mathrm{CO}_{2}$ emitted to the atmosphere (Siegenthaler and Sarmiento, 1993; Watson et al., 1995). In this sense, the Atlantic Ocean is considered to be the most important $\mathrm{CO}_{2}$ sink (Takahashi et al., 1997). In particular, the North Atlantic Ocean is an area of deep-water formation where much of the $\mathrm{CO}_{2}$ taken up is sequestered on centennial time scales because of the large scale meridional overturning circulation.

The gravitational settling of biogenic debris from the photic zone transports carbon to the deep ocean. This debris consists of soft-tissue organic compounds and hard siliceous and calcareous skeletons, and its remineralization in the water column contributes to the creation and maintainance of concentration gradients in the ocean. This process is known as the "biological pump", divided into the "soft-tissue pump" and the "carbonate pump" (Volk and Hoffert, 1985). 
The anthropogenic $\mathrm{CO}_{2}$ uptake is calculated by correcting total inorganic carbon for these processes, regeneration of organic matter and dissolution of particulate carbonates, as independently proposed by Brewer (1978) and Chen and Millero (1979), and reformulated by Gruber et al. (1996) (hereinafter GSS'96) using tracer ages and a conservative tracer called C*, which is similar to the conservative parameter CAO earlier described by Ríos et al. (1989).

Several estimates of anthropogenic $\mathrm{CO}_{2}$ have been performed in the North Atlantic Ocean using historical data sets such as GEOSECS or TTO (Chen, 1982; Gruber et al., 1996). Recently, other inventories have been done relying on more accurate data sets (Körtzinger et al., 1998; Wanninkhof et al., 1999a).

In this work we analyse some of the caveats of the most widely used methodology for estimating anthropogenic $\mathrm{CO}_{2}$, that proposed by GSS'96, with especial emphasis on the evaluation of preformed alkalinity by means of modelling the alkalinity pump using sediment trap data. Our analysis was performed using a publicly-available high-quality data set for $\mathrm{CO}_{2}$ measurements from the North Atlantic Ocean Atmosphere Carbon Exchange Study. We selected the National Oceanic and Atmospheric Administration Cruise Leg IIB (OacesNAtlIIB-93, July/August, 1993) covering from $35^{\circ} \mathrm{N}$ to $63^{\circ} \mathrm{N}$ along $20^{\circ} \mathrm{W}$ (www.aoml.noaa.gov/ocd/oaces). The anthropogenic $\mathrm{CO}_{2}$ inventory along this leg is calculated introducing improvements on the GSS'96 methodology, and finally the consistency of our results is discussed.

\section{FORMULATION.}

\subsection{The back-calculation technique.}

The back-calculation technique as formulated by GSS' 96 uses a conservative parameter C*, which corrects total inorganic carbon for biological activity, both the soft-tissue and the carbonate pumps. $\mathrm{C}^{*}$ can be expressed in terms of current or preformed variables:

$$
\mathrm{C}^{*}(\tau)=\mathrm{C}_{\mathrm{T}}+\mathrm{O}_{2} / \mathrm{R}_{\mathrm{C}}-1 / 2\left(\mathrm{TA}+\mathrm{O}_{2} / \mathrm{R}_{\mathrm{N}}\right)=\mathrm{C}_{\mathrm{T}}^{0}(\tau)+\mathrm{O}_{2}{ }^{0} / \mathrm{R}_{\mathrm{C}}-1 / 2\left(\mathrm{TA}^{0}+\mathrm{O}_{2}{ }^{0} / \mathrm{R}_{\mathrm{N}}\right)
$$

where $\mathrm{C}_{T}$ is the total inorganic carbon concentration, $\mathrm{O}_{2}$ is dissolved oxygen, TA stands for alkalinity, $\mathrm{R}_{\mathrm{C}}\left(=-\Delta \mathrm{O}_{2} / \Delta \mathrm{C}\right)$ and $\mathrm{R}_{\mathrm{N}}\left(=-\Delta \mathrm{O}_{2} / \Delta \mathrm{N}\right)$ are stoichiometric coefficients and $\tau$ stands for the water mass age. $\mathrm{C}^{*}(\tau)$, as $\mathrm{NO}$ or PO (Broecker, 1974), reflects the origin of the water mass, being independent of the biological activity accounted for since the water mass lost contact with the atmosphere (that is, $\tau$ ) but containing the time-increasing $\mathrm{CO}_{2}$ anthropogenic signal taken up by atmospheric contact at the outcrop region. $\mathrm{C}_{\mathrm{T}}^{0}(\tau)$ stands for the preformed inorganic carbon concentration the water mass acquires when formed at oxygen saturation $\left(\mathrm{O}_{2}{ }^{0}\right)$ and preformed alkalinity $\left(\mathrm{TA}^{0}\right)$ conditions. Oxygen saturation is calculated from the equation of Benson and Krause (UNESCO, 1986). As alkalinity is not affected by the anthropogenic $\mathrm{CO}_{2}$ increase in the atmosphere, present and pre-industrial alkalinity preformed values are equal and can be derived from contemporary winter measurements of surface TA. In this sense, $\mathrm{TA}^{0}$ is usually calculated 
from linear regressions using conservative properties such as salinity, potential temperature, PO or NO (Broecker, 1974). Different equations have been proposed for TA ${ }^{0}$ (Chen and Pytkowicz, 1979; Chen et al., 1990; GSS'96; Millero et al., 1998; Sabine et al., 1999; Wanninkhof et al., 1999a).

GSS'96 states that there is an effective and time-independent $\mathrm{CO}_{2}$ air-sea disequilibrium $\left(\Delta \mathrm{C}_{\mathrm{Tdis}}\right)$ when the water looses contact with the atmosphere, thus the same whether the water mass is formed at a certain time $(\tau)$ or in pre-industrial times $(\pi)$ :

$\Delta \mathrm{C}_{\mathrm{Tdis}}=\mathrm{C}_{\mathrm{T}}^{0}(\tau)-\mathrm{C}_{\mathrm{T}}^{\mathrm{eq}}\left(\theta, \mathrm{S}, \mathrm{TA}^{0}, \mathrm{pCO}_{2}{ }^{\tau}\right)=\mathrm{C}_{\mathrm{T}}^{0}(\pi)-\mathrm{C}_{\mathrm{T}}^{\mathrm{eq}}\left(\theta, \mathrm{S}, \mathrm{TA}^{0}, \mathrm{pCO}_{2}{ }^{\pi}\right)$

where $\mathrm{C}_{\mathrm{T}}^{0}$ are the preformed $\mathrm{C}_{\mathrm{T}}$ values when the water mass is currently formed, $\mathrm{C}_{\mathrm{T}}^{0}(\tau)$, and in pre-industrial times, $\mathrm{C}_{\mathrm{T}}{ }^{0}(\pi)$, calculated according to equation $1 . \mathrm{C}_{\mathrm{T}}{ }^{\text {eq }}$ are the $\mathrm{C}_{\mathrm{T}}$ values in equilibrium with the atmospheric partial pressure of $\mathrm{CO}_{2}$ when the water mass is currently formed $\left(\mathrm{pCO}_{2}{ }^{\tau}\right)$ and in pre-industrial times $\left(\mathrm{pCO}_{2}{ }^{\pi}\right) \cdot \mathrm{C}_{\mathrm{T}}{ }^{\mathrm{eq}}$ are calculated from thermodynamic equations as a function of hydrographic variables, potential temperature $(\theta)$ and salinity (S), preformed alkalinity and the corresponding atmospheric $\mathrm{pCO}_{2}$ (Neftel et al., 1994). $\Delta \mathrm{C}_{\text {Tdis }}$ reflects the $\mathrm{CO}_{2}$-air-sea disequilibrium in $\mathrm{C}_{\mathrm{T}}$ when water masses are formed once carbon is corrected for biology.

GSS'96 defined the conservative variable $\Delta C^{*}(\tau)$, which depends on the anthropogenic input, and thus the water mass age $(\tau)$, and includes the steady-state disequilibrium term:

$$
\Delta \mathrm{C}^{*}(\tau)=\mathrm{C}_{\mathrm{ANT}}+\Delta \mathrm{C}_{\mathrm{Tdis}}=\mathrm{C}^{*}(\tau)-\mathrm{C}^{*}(\pi)+\Delta \mathrm{C}_{\mathrm{Tdis}}
$$

Combining 1 to 3 :

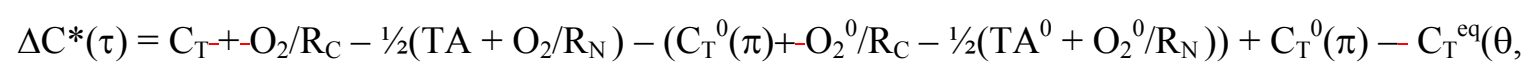

$\left.\mathrm{S}, \mathrm{TA}^{0}, \mathrm{pCO}_{2}{ }^{\pi}\right)=\mathrm{C}_{\mathrm{T}}-\mathrm{AOU} / \mathrm{R}_{\mathrm{C}}-1 / 2\left(\Delta \mathrm{TA}+\mathrm{AOU} / \mathrm{R}_{\mathrm{N}}\right)-\mathrm{C}_{\mathrm{T}}{ }^{\mathrm{eq} \pi}$

(4)

where $\mathrm{C}_{\mathrm{T}}{ }^{\mathrm{eq} \pi}$ denotes the $\mathrm{C}_{\mathrm{T}}{ }^{\mathrm{eq}}\left(\theta, \mathrm{S}, \mathrm{TA}^{0}, \mathrm{pCO}_{2}{ }^{\pi}\right)$ term, AOU denotes Apparent Oxygen Utilization and $\Delta \mathrm{TA}=\mathrm{TA}-\mathrm{TA}^{0}$. Finally, recombining equation 3 and 4 :

$\mathrm{C}_{\mathrm{ANT}}=\mathrm{C}_{\mathrm{T}}-\mathrm{AOU} / \mathrm{R}_{\mathrm{C}}-1 / 2\left(\Delta \mathrm{TA}+\mathrm{AOU} / \mathrm{R}_{\mathrm{N}}\right)-\mathrm{C}_{\mathrm{T}}^{\mathrm{eq} \pi}-\Delta \mathrm{C}_{\mathrm{Tdis}}$

The GSS'96 disequilibrium term is evaluated by density intervals employing two different methods but in both assuming that the air-sea disequilibrium has remained constant over time. In uncontaminated regions along isopycnals where no anthropogenic carbon is supposed, $\Delta \mathrm{C}^{*}(\tau)$ reflects the effective air-sea disequilibrium. Therefore, $\Delta \mathrm{C}_{\text {Tdis }}$ is calculated as the mean of $\Delta \mathrm{C}^{*}(\tau)$ within a given isopycnal interval:

$\Delta \mathrm{C}_{\mathrm{Tdis}}=\left.\Delta \mathrm{C}^{*}(\tau)\right|_{\sigma=\mathrm{cte}}$

On shallower surfaces with measurable tracer concentrations, the disequilibrium is estimated from the corresponding atmospheric $\mathrm{CO}_{2}$ level matching a tracer-estimated age $\left(\mathrm{pCO}_{2}{ }^{\tau}\right)$. GSS'96 
uses tritium- ${ }^{3} \mathrm{He}$ ages as an approximation to true ages, disregarding non-linear effects on the tracer age and assuming that the transport is mainly advective. The $\mathrm{CO}_{2}$ disequilibrium is evaluated as:

$$
\Delta \mathrm{C}_{\text {Tdis }}=\left.\left[\mathrm{C}_{\mathrm{T}}-\mathrm{AOU} / \mathrm{R}_{\mathrm{C}}-1 / 2 \cdot\left(\Delta \mathrm{TA}+\mathrm{AOU} / \mathrm{R}_{\mathrm{N}}\right)-\mathrm{C}_{\mathrm{T}}{ }^{\mathrm{eq}}\left(\theta, \mathrm{S}, \mathrm{TA}^{0}, \mathrm{pCO}_{2}{ }^{\tau}\right)\right]\right|_{\sigma=c \text { cte }}
$$

As a consequence of assuming steady-state in the disequilibrium term (equation 2), the intrinsic definition of $\mathrm{C}_{\mathrm{ANT}}$ can also be expressed as:

$$
\mathrm{C}_{\mathrm{ANT}}=\mathrm{C}_{\mathrm{T}}{ }^{0}(\tau)-\mathrm{C}_{\mathrm{T}}{ }^{0}(\pi)=\mathrm{C}_{\mathrm{T}}{ }^{\mathrm{eq}}\left(\theta, \mathrm{S}, \mathrm{TA}^{0}, \mathrm{pCO}_{2}{ }^{\tau}\right)-\mathrm{C}_{\mathrm{T}}{ }^{\mathrm{eq}}\left(\theta, \mathrm{S}, \mathrm{TA}^{0}, \mathrm{pCO}_{2}{ }^{\pi}\right)
$$

The second half of equation 8 substituted in 5 yields equation 7 , thus, equation 7 is a consequence of assuming a steady-state disequilibrium.

Summing up, the GSS'96 methodology assumes: i) total alkalinity is not significantly affected by the $\mathrm{CO}_{2}$ increase in the atmosphere; ii) the effective $\mathrm{CO}_{2}$ air-sea disequilibrium has stayed constant within the outcrop region of a particular isopycnal surface; iii) water transport is mainly along isopycnal surfaces.

According to equation $8, \mathrm{C}_{\mathrm{ANT}}$ can be directly derived as the difference between $\mathrm{C}_{\mathrm{T}}$ in equilibrium with the atmospheric $\mathrm{CO}_{2}$ content when the water mass is formed at a certain age $(\tau)$ and in pre-industrial $(\pi)$ times, as calculated in Tait et al. (2000) and Thomas and Ittekkot (2001). This is not a shortcut, as stated by GSS'96, but a direct consequence of the assumption of a constant $\mathrm{CO}_{2}$ disequilibrium with time. With equation 8 no $\mathrm{C}_{\mathrm{T}}$ measurements are even necessary; the key factor is an exact knowledge of the water mass age. Although the individual $\mathrm{C}_{\mathrm{T}}{ }^{\text {eq }}$ calculations are affected by inaccuracies in the estimation of $\mathrm{TA}^{0}$ and in the chosen set of thermodynamic constants, the final errors in $\mathrm{C}_{\mathrm{ANT}}$ due to both sources of uncertainty practically cancel out, as both $\mathrm{C}_{\mathrm{T}}{ }^{\text {eq }}$ are modified in the same manner but with opposing sign.

\subsection{Inorganic to Organic carbon decomposition Ratio (IOR).}

The ratio between the carbon variation due to dissolution of calcium carbonate $\left(\Delta \mathrm{C}_{\mathrm{i}}\right)$ and that derived from the decomposition of organic matter $\left(\Delta \mathrm{C}_{\mathrm{o}}\right)$ can be expressed as:

$$
\mathrm{IOR}=\frac{\Delta \mathrm{C}_{\mathrm{i}}}{\Delta \mathrm{C}_{0}}=\frac{1 / 2\left(\mathrm{TA}-\mathrm{TA}^{0}+\mathrm{AOU} / \mathrm{R}_{\mathrm{N}}\right)}{\mathrm{AOU} / \mathrm{R}_{\mathrm{C}}}=\mathrm{R}_{\mathrm{C}}\left(\Delta \mathrm{TA} / \mathrm{AOU}+1 / \mathrm{R}_{\mathrm{N}}\right) / 2
$$

where all the terms were explained previously. Thus, if IOR and AOU are known the variation of alkalinity due to redissolution of carbonates $(\Delta \mathrm{TA})$ is calculated as:

$$
\Delta \mathrm{TA}=\left(2 \cdot \mathrm{IOR} / \mathrm{R}_{\mathrm{C}}-1 / \mathrm{R}_{\mathrm{N}}\right) \cdot \mathrm{AOU}
$$

The ratio between soft and hard material decomposition varies with depth. The upper ocean is supersaturated with calcium carbonate (Broecker and Peng, 1982; Takahashi et al., 1981), and therefore the regeneration of inorganic carbon is predominantly by soft-tissue remineralisation in this upper layer (Honjo et al., 1982; Honjo and Manganini, 1993). However, a recent review of the 
global carbonate budget performed by Milliman et al. (1999) showed evidence that a considerable portion of surface-produced calcite, as much as $60-80 \%$, dissolves in the upper $1000 \mathrm{~m}$, above the lysocline, as a result of biological mediation. In deeper waters, the dissolution of hard material predominates because of the increased pressure, decreased temperature and the longer residence time (Broecker and Peng, 1982).

Broecker and Peng (1982), using GEOSECS data covering various oceans, estimated an IOR of 0.25 for the permanent thermocline and about 1 for deep waters. Takahashi et al. (1985) calculated IOR values for the North Atlantic from 0.09 to 0.15. In the Eastern North Atlantic Ocean Ríos et al. (1995) found an IOR of 0.16 for the upper $2300 \mathrm{~m}$ and 1.05 for deeper waters.

Silicon is also exported, as opal in biogenic debris (mostly as diatom frustules), and mainly redissolved in the deep ocean. As for calcium carbonate, most opaline silica dissolution takes place below the main thermocline. Thus, the high covariation between the alkalinity and the silicate fields (Brewer et al., 1995; Broecker and Peng, 1982; Ríos et al., 1995), probably exists because the dissolution of these hard structures is biologically stimulated in micro-environments such as marine snow, zooplankton guts, etc.

\section{EVIDENCE FOR AN INACCURATE ESTIMATION OF TA ${ }^{0}$ AND $_{\mathrm{T}}{ }^{\mathrm{eq}}$.}

In this section we demonstrate that the $\mathrm{TA}^{0}$ parameterization proposed by GSS' 96 and other authors contradicts the knowledge about calcium carbonate dissolution in the oceans. A new parameterization is introduced and validated. Likewise, several improvements are also introduced to estimate the $\mathrm{C}_{\mathrm{T}}$ in equilibrium with the pre-industrial atmosphere, $\mathrm{C}_{\mathrm{T}}{ }^{\text {eq } \pi}$.

\subsection{The alkalinity pump, estimation of $\mathrm{TA}^{0}$.}

As previously mentioned, there is a good covariation between the processes controlling alkalinity and silicate variability. In this sense, the silicate increase due to dissolution of opal $(\Delta \mathrm{Si})$ can be estimated by an approach similar to that used to determine the alkalinity variation due to dissolution of carbonate $(\Delta \mathrm{TA})$. As $\Delta \mathrm{TA}$ is $\mathrm{TA}-\mathrm{TA}^{0}, \Delta \mathrm{Si}$ is estimated as the difference between the current silicate concentration and the preformed value $\left(\Delta \mathrm{Si}=\mathrm{Si}_{-} \mathrm{Si}^{0}\right)$. As an approximation to the winter mixed layer, and thus preformed, silicate concentrations, a linear relationship is obtained between silicate and potential temperature for the layer between 50 and $200 \mathrm{~m}$ using data from the OacesNAtlIIB-93:

$\mathrm{Si}^{0} \pm 0.93=(10.2 \pm 0.5)-(0.67 \pm 0.05) \cdot \theta \quad \mathrm{r}^{2}=0.69 \quad \mathrm{n}=92$

where $\mathrm{Si}^{0}$ is preformed silicate and $\theta$ is potential temperature. Equation 11 can be applied for waters with $\theta>2^{\circ} \mathrm{C}$, with no Antarctic influence; otherwise it would underestimate $\mathrm{Si}^{0}$.

The relationship between the increase of silicate and alkalinity due to dissolution of opal and calcium carbonate, respectively, is shown in Figure 1. $\Delta \mathrm{Si}$ was calculated from equation 11 and 
$\Delta$ TA using different parameterizations for TA ${ }^{0}$ : GSS'96, Millero et al. (1998) and Wanninkhof et al. (1999a). The GSS'96 TA ${ }^{0}$ function was obtained from top $100 \mathrm{~m}$ data from the whole Atlantic Ocean and reported with an uncertainty of $11 \mu \mathrm{mol} \cdot \mathrm{kg}^{-1}$. The Millero et al. (1998) TA ${ }^{0}$ function was obtained from surface data from the whole North Atlantic Ocean $\left(30^{\circ} \mathrm{N}-80^{\circ} \mathrm{N}\right)$, reported with an uncertainty of $5 \mu \mathrm{mol} \cdot \mathrm{kg}^{-1}$. The Wanninkhof et al. (1999a) $\mathrm{TA}^{0}$ parameterization was obtained from the particular data set obtained along about $25 / 32^{\circ} \mathrm{W}$ from $43^{\circ} \mathrm{S}$ to $62^{\circ} \mathrm{N}$, occupied as part of NOAA-OACES during July 1991 and July/August 1993, this TA ${ }^{0}$ parameterization was calculated with top $100 \mathrm{~m}$ data and reported with an uncertainty of $5.2 \mu \mathrm{mol} \cdot \mathrm{kg}^{-1}$.

The first two parameterizations give systematic negative values of $\Delta \mathrm{TA}$ despite the net increase of silicate from 0 to $10 \mu \mathrm{mol} \cdot \mathrm{kg}^{-1}$. However, the Wanninkhof et al. (1999a) TA ${ }^{0}$ function yields positive $\Delta \mathrm{TA}$ in the former range. As mentioned previously, there is an increasing amount of evidence suggesting a considerable dissolution of calcium carbonate above the chemical lysocline (Milliman et al., 1999; Mintrop et al., 1999; Yu et al., 2001). Hence, the first two TA ${ }^{0}$ parameterizations seem questionable. This fact is also suggested by the variability with depth of the IOR values calculated by substituting TA ${ }^{0}$ from GSS' 96 in equation 9 (Figure 2). Once again there exists a systematic shift to negative values of IOR in the upper $2000 \mathrm{~m}$, indicating precipitation of calcium carbonate contrary to the conclusions of Milliman et al. (1999) and the previously cited values for IOR in the upper water column [0.25 from Broecker and Peng (1982), 0.16 from Ríos et al. (1995)].

The Millero et al. (1998) $\mathrm{TA}^{0}$ parameterization is based on surface measurements of TA all over the North Atlantic Ocean, expressed as a function of temperature. Most of this data was collected in summer or spring. Consequently, they do not reflect the winter-time conditions, being affected by seasonal warming. Accordingly, $\mathrm{TA}^{0}$ values are overestimated because of the shift to higher temperatures in the $\mathrm{TA}^{0}$ function.

The GSS'96 TA ${ }^{0}$ empirical function relies on data from the top $100 \mathrm{~m}$ and depends on the conservative parameters salinity and PO (Broecker, 1974). This parameterization was also obtained from data collected primarily during summer conditions. However, it should yield reliable results for winter, as salinity normalized alkalinity has a small seasonal cycle (Takahashi et al., 1993), as also argued by GSS'96. We speculate that the GSS'96 TA ${ }^{0}$ function must suffer from biases in the initial TA data set: the precision of TA measurements during GEOSECS (1972-1978) and TTONAS (1981) was low ( \pm 9 and $\pm 5 \mu \mathrm{mol} \cdot \mathrm{kg}^{-1}$, respectively, Brewer et al., 1986) compared to current measurements (less than $1 \mu \mathrm{mol} \cdot \mathrm{kg}^{-1}$, Mintrop et al., 2000). It may also suffer from the influence of high TA values due to the predominance of South Atlantic samples in the GSS'96 analysis and finally of a bias in the data values for alkalinity, oxygen, phosphate and salinity, as taken from the seasonal thermocline, especially oxygen which is affected by outgassing. 
The $\mathrm{TA}^{0}$ function proposed by Wanninkhof et al. (1999a) also uses TA, salinity and NO data from top $100 \mathrm{~m}$ but in contrast to Millero et al. (1998) and GSS'96 TA ${ }^{0}$ functions yields positive values for $\Delta \mathrm{TA}$ in the upper layer. Therefore it is presumably a correct model for the $\mathrm{TA}^{0}$ of water masses in the North Atlantic.

In order to avoid the use of any $\mathrm{TA}^{0}$ parameterization, we adjusted IOR as a polynomial function with depth. This polynomial was obtained as the best fit, in a least square sense, for the IOR values calculated from equation 9 , where $\Delta \mathrm{TA}$ is calculated as $m \cdot \Delta \mathrm{Si},\left(\Delta \mathrm{Si}=\mathrm{Si}_{-} \mathrm{Si}^{0}, \mathrm{Si}^{0}\right.$ from equation 11). Therefore, the polynomial equation and $m$ are calculated iteratively until the best fit to the data is obtained. The final polynomial expression for IOR with depth was obtained with $m=1.42$, thus:

IOR $\pm 0.03=0.003117 \cdot z^{5}-0.04608 \cdot z^{4}+0.2313 \cdot z^{3}-0.4457 \cdot z^{2}+0.3489 \cdot z+0.0371$

$\mathrm{r}^{2}=0.94 \quad \mathrm{n}=549$

where $\mathrm{z}$ is depth in $\mathrm{km}$. The individual values of IOR and their fit (equation 12) are shown in Figure 2. The error finally incurred in $\Delta \mathrm{TA}$ is evaluated by an error propagation analysis in equation 10. IOR and AOU initial values are modified in \pm 0.03 _and $\pm 2 \mu \mathrm{mol} \cdot \mathrm{kg}^{-1}$ intervals with a normally distributed random number, then IOR is recalculated. This modification is performed a hundred times over the whole set of samples. The standard deviation of the difference between the initial and modified $\Delta \mathrm{TA}\left( \pm 1.4 \mu \mathrm{mol} \cdot \mathrm{kg}^{-1}\right)$ is considered to be the uncertainty of our $\Delta \mathrm{TA}$ estimation. Considering a maximum error in TA of $\pm 2 \mu \mathrm{mol} \cdot \mathrm{kg}^{-1}$, the final uncertainty in $\mathrm{TA}^{0}$ is $\pm 3.4 \mu \mathrm{mol} \cdot \mathrm{kg}^{-1}$.

The IOR values are in the range within 0.12-0.60, in agreement with sediment trap data from the North Atlantic and hydrological water mass analysis (Broecker and Peng, 1982; Honjo and Manganini, 1993; Martin et al., 1993; Ríos et al., 1995; Takahashi et al., 1985). On the other hand, $\Delta \mathrm{TA} / \Delta \mathrm{Si}=1.42$ implies a mean $\mathrm{CaCO}_{3}: \mathrm{SiO}_{2}$ ratio for the whole water column of 0.71 . The open ocean calcite and opal decomposition in the water column, according to Milliman et al. (1999) and Tréguer et al. (1995), are $4710^{12} \mathrm{~mol} \cdot \mathrm{y}^{-1}$ and $90.910^{12} \mathrm{~mol} \cdot \mathrm{y}^{-1}$ respectively, thus, a mean $\mathrm{CaCO}_{3}: \mathrm{SiO}_{2}$ decomposition ratio of 0.52 , value in reasonable agreement with our estimation.

According to Berger and Herguera (1992) a $\mathrm{CaCO}_{3}: \mathrm{SiO}_{2}$ ratio of 0.71 is expected for an area with a mean organic carbon flux of $10 \mathrm{mmol} \cdot \mathrm{m}^{-2} \cdot \mathrm{d}^{-1}$, which is in close agreement with their productivity value for the Eastern North Atlantic Ocean (Martin et al., 1993). Higher $\mathrm{CaCO}_{3}: \mathrm{SiO}_{2}$ ratios, around 0.95 , were measured in sediment traps deployed at the NABE site below $3100 \mathrm{~m}$ (Newton et al., 1994).

With the aim of validating our proposed parameterization for $\Delta \mathrm{TA}$ (equation 10 as a function of equation 12) we proposed a simple 1D steady state model simulating the biological pump, thus, the decomposition of hard and soft-tissue biogenic matter. As a proxy for the whole North Atlantic Ocean, it has been applied over the OacesNAtIIIB-93 data set and validated against sediment trap 
profile data obtained by Martin et al. (1993) at the NABE site. Thus, the decomposition ratios (IOR) are adjusted with the ratio between organic and inorganic matter accumulated in sediment traps (rain ratios).

The decomposition of biogenic debris between two horizontal layers produces a gain of AOU and $\Delta \mathrm{TA}$ in time:

$$
-\frac{\partial \mathrm{F}_{\mathrm{Co}}}{\partial \mathrm{z}}=\frac{\rho}{\mathrm{R}_{\mathrm{C}}} \cdot \frac{d \mathrm{AOU}}{d \mathrm{t}} \quad-\frac{\partial \mathrm{F}_{\mathrm{Ci}}}{\partial \mathrm{z}}=\rho \cdot \frac{d \Delta \mathrm{TA}}{d \mathrm{t}}
$$

where $\mathrm{F}_{\mathrm{Co}}$ and $\mathrm{F}_{\mathrm{Ci}}$ are the organic and inorganic carbon fluxes, respectively, $\mathrm{z}$ is depth, $\mathrm{t}$ is time, $\rho$ is seawater density and $\mathrm{R}_{\mathrm{C}}$ the stoichiometric $-\Delta \mathrm{O}_{2} / \Delta \mathrm{C}$ ratio. The transport equation in three dimensions for a non-conservative variable ( $\mathrm{NCV}, \mathrm{AOU}$ or $\triangle \mathrm{TA}$, in this case) may be written as:

$$
\frac{\mathrm{dNCV}}{\mathrm{dt}}=\frac{\partial \mathrm{NCV}}{\partial \mathrm{t}}+\mathrm{v}_{\mathrm{z}} \frac{\partial \mathrm{NCV}}{\partial \mathrm{z}}+\mathrm{v}_{\mathrm{x}} \frac{\partial \mathrm{NCV}}{\partial \mathrm{x}}+\mathrm{v}_{\mathrm{y}} \frac{\partial \mathrm{NCV}}{\partial \mathrm{y}}-\mathrm{K} \cdot \nabla^{2} \mathrm{NCV}
$$

where $\mathrm{K}$ is the eddy diffusivity and $\mathrm{v}$ are the different components of the velocity.

Considering the relatively scarce information about horizontal variability in the sediment trap profiles, we assume the rain ratios reported at the NABE site as representative of the North Atlantic. Consequently, the 3D model simplifies to 1D by basin-scale integration. Thus, subduction and vertical mixing are considered as the main processes ventilating subsurface waters. Moreover, if the mean AOU and $\triangle \mathrm{TA}$ along OacesNAtlIIB-93 are regarded as representative of the whole North Atlantic and in steady state, their temporal variation can be related to their vertical gradient by:

$$
\frac{\mathrm{dNCV}}{\mathrm{dt}}=\mathrm{v}_{\mathrm{z}} \frac{\partial \mathrm{NCV}}{\partial \mathrm{z}}-\mathrm{K} \cdot \nabla^{2} \mathrm{NCV}
$$

Substituting equation 15 in equations 13 and integrating between two different depths we finally obtain:

$$
\begin{aligned}
& \mathrm{F}_{\mathrm{Coz}_{2}}=\mathrm{F}_{\mathrm{Coz}_{1}}-\frac{\rho}{\mathrm{R}_{\mathrm{C}}} \cdot\left\{\mathrm{v}_{\mathrm{z}} \cdot\left(\mathrm{AOU}_{\mathrm{z}_{2}}-\mathrm{AOU}_{\mathrm{z}_{1}}\right)-\mathrm{K}_{\mathrm{z}}\left(\left.\frac{\mathrm{dAOU}}{\mathrm{dz}}\right|_{\mathrm{z}_{2}}-\left.\frac{\mathrm{dAOU}}{\mathrm{dz}}\right|_{\mathrm{z}_{1}}\right)\right\} \\
& \mathrm{F}_{\mathrm{Ci}_{z_{2}}}=\mathrm{F}_{\mathrm{Ci}_{\mathrm{z}_{1}}}-\rho \cdot\left\{\mathrm{v}_{\mathrm{z}} \cdot\left(\Delta \mathrm{TA}_{\mathrm{z}_{2}}-\Delta \mathrm{TA}_{\mathrm{z}_{1}}\right)-\mathrm{K}_{\mathrm{z}}\left(\left.\frac{\mathrm{d} \Delta \mathrm{TA}}{\mathrm{dz}}\right|_{\mathrm{z}_{2}}-\left.\frac{\mathrm{d} \Delta \mathrm{TA}}{\mathrm{dz}}\right|_{\mathrm{z}_{1}}\right)\right\}
\end{aligned}
$$

Therefore, the flux of organic and inorganic carbon at a given depth layer can be calculated from the corresponding initial fluxes at the above layer and the variation of AOU and $\Delta \mathrm{TA}$ between both of them, if the vertical turnover velocity and vertical diffusivity are known. In this sense, $v_{z}$ was parameterized as $\mathrm{v}_{\mathrm{z}}=0.4 \cdot(\mathrm{z} / 100)^{-0.3}\left(\mathrm{v}_{\mathrm{z}}\right.$ in $\mathrm{m}^{-\mathrm{d}^{-1}}$ and $\mathrm{z}$ is depth in $\left.\mathrm{km}\right)$ in order to adjust our 
organic carbon fluxes calculated from the mean vertical profile of AOU (obtained from the OacesNAtlIIB-93 data) with those measured by Martin et al. (1993) (Table 1). The vertical diffusive terms, using typical $\mathrm{K}_{\mathrm{z}}$ values between 0.001 and $0.0002 \mathrm{~m} \cdot \mathrm{s}^{-2}$, are negligible compared to the advective terms. Predicted values for $\mathrm{v}_{\mathrm{z}}$ (from 0.16 to $0.36 \mathrm{~m} \cdot \mathrm{d}^{-1}$ ) are in agreement with typical rates of subduction and entrainment given by Marshall et al. (1993) for the North Atlantic, and also with the decreasing meridional water flux in the mixed layer with increasing density (i.e. depth) (Huang, 1989).

Dissolution of calcium carbonate at the NABE site, as representative for the northern North Atlantic, is calculated as $\Delta \mathrm{Ci}=\mathrm{IOR} \cdot \mathrm{AOU} / \mathrm{R}_{\mathrm{C}}$ with our IOR equation (equation 12 ) and as $\Delta \mathrm{Ci}=$ $1 / 2 \cdot\left(\mathrm{TA}^{-} \mathrm{TA}^{0}+\mathrm{AOU} / \mathrm{R}_{\mathrm{N}}\right)$ using the $\mathrm{TA}^{0}$ formula from GSS'96 (See Table 1 and Figure 3 ). In the former approximations the AOU and TA mean profiles along the OacesNAtlIIB-93 are used along with the $\mathrm{R}_{\mathrm{C}}$ and $\mathrm{R}_{\mathrm{N}}$ from Anderson and Sarmiento (1994). Both the organic and inorganic carbon fluxes estimated using our model present a good agreement with those measured by Martin et al. (1993) (See Table 1 and Figure 3). The inorganic carbon flux calculated with TA ${ }^{0}$ from GSS'96 agrees with the measured and modelled results in the upper $500 \mathrm{~m}$ (Table 1 and Figure 3). At deeper levels the inorganic carbon flux using the TA ${ }^{0}$ from GSS'96 is notably overestimated, indicating a low dissolution rate of calcium carbonate. Although sediment trap data could be affected by hydrodynamic and other factors, leading to a significant "over/undertrapping" (Yu et al., 2001), the inorganic and organic fluxes are both affected in the same manner. It must also be taken into account that water masses integrate the dissolution of biogenic material over time and space, hence attenuating the high variability of the rain ratios seen in the sediment trap data. Therefore, we consider that trap biases not relevant when measured and calculated rain ratios are compared.

\subsection{Effect of the alkalinity pump and new improvements on $\mathrm{C}_{\mathrm{T}}{ }^{\mathrm{eq} \pi}$.}

Having obtained a better parameterization of $\mathrm{TA}^{0}$ as a function of IOR (equations 10 and 12), we proceed to address its effect on the estimation of the pre-industrial equilibrium total inorganic carbon, $\mathrm{C}_{\mathrm{T}}{ }^{\mathrm{eq} \pi}$. Additional improvements on $\mathrm{C}_{\mathrm{T}}{ }^{\mathrm{eq} \pi}$ are proposed.

$\mathrm{C}_{\mathrm{T}}{ }_{\mathrm{T}}^{\mathrm{eq} \pi}$ is calculated from $\mathrm{TA}^{0}$, the pre-industrial level of atmospheric partial pressure of $\mathrm{CO}_{2}$ (Neftel et al., 1994) and using a given set of $\mathrm{CO}_{2}$ constants. GSS'96 used their $\mathrm{TA}^{0}$ parameterization, a constant value for pre-industrial $\mathrm{pCO}_{2}$ equal to $280 \mu \mathrm{atm}$ and the set of thermodynamic constants from Goyet and Poisson (1989). We have already shown that their $\mathrm{TA}^{0}$ parameterization gives rather high values. On the other hand, atmospheric $\mathrm{pCO}_{2}$ is a function not only of the molar fraction of $\mathrm{CO}_{2}$ but also of the water vapor partial pressure and total atmospheric pressure (DOE, 1994; Wanninkhof and Thoning, 1993). Takahashi et al. (1993) showed that the best set of $\mathrm{CO}_{2}$ thermodynamic constants is that by Mehrbach et al. (1973). Recently, other 
thermodynamical and field studies (Johnson et al., 1999; Lee et al., 2000; Ríos and Pérez, 1999; Ríos et al., 2001; Tapp et al., 2000; Wanninkhof et al., 1999b) reached the same conclusion.

In order to clearly show the variation of $\mathrm{C}_{\mathrm{T}}{ }^{\mathrm{eq} \pi}$ under different conditions, $\mathrm{TA}^{0}$ parameterization, $\mathrm{pCO}_{2}{ }^{\pi}$ calculation and set of thermodynamic constants, we calculated $\mathrm{C}_{\mathrm{T}}{ }^{\mathrm{eq} \pi}$ for the OacesNAtlIIB-93 data set following these combinations:

a) $\mathrm{TA}^{0}$ from GSS'96, a constant value for $\mathrm{pCO}_{2}{ }^{\pi}$ equal to $280 \mu \mathrm{atm}$ and the Goyet and Poisson (1989) constants. This is the GSS'96 option.

b) $\mathrm{TA}^{0}$ from GSS'96, $\mathrm{pCO}_{2}{ }^{\pi}$ calculated as a function of a molar fraction of $278.2 \mathrm{ppm}$ (Neftel et al., 1994; Sarmiento et al., 1995), water vapor pressure and the constants of Goyet and Poisson (1989).

c) The same as before but with the Merhbach et al. (1973) constants.

d) $\mathrm{TA}^{0}$ obtained from our equations 10 and $12, \mathrm{pCO}_{2}{ }^{\pi}$ calculated as a function of a molar fraction of $278.2 \mathrm{ppm}$, water vapor pressure and the Merhbach et al. (1973) constants.

Figure 4 shows salinity-normalised $\mathrm{C}_{\mathrm{T}}^{\mathrm{eq} \pi}\left(\mathrm{NC}_{\mathrm{T}}{ }^{\mathrm{eq} \pi}\right)$ values for the previous sets of combinations against potential temperature. Option (a) $\mathrm{NC}_{\mathrm{T}}{ }^{\mathrm{eq} \pi}$ present the highest values for the whole temperature range. Including the effect of water vapor in the calculation of $\mathrm{pCO}_{2}{ }^{\pi}$ (option $\mathrm{b}$ ) reduces $\mathrm{NC}_{\mathrm{T}}{ }^{\text {eq } \pi}$ by an average of $5 \pm 1 \mu \mathrm{mol} \cdot \mathrm{kg}^{-1}$, with a maximum effect of $-10 \mu \mathrm{mol} \cdot \mathrm{kg}^{-1}$ at high temperatures, $15^{\circ} \mathrm{C}$. Including the set of constants from Mehrbach et al. (1973) (option c) gives $\mathrm{NC}_{\mathrm{T}}{ }^{\text {eq } \pi}$ values that are $14 \mu \mathrm{mol} \cdot \mathrm{kg}^{-1}$ lower than GSS'96 values at low temperatures. On the other hand at high temperatures the effect of including the Mehrbach et al. (1973) constants counteracts half of the effect due to including the water vapor pressure in the formulation. Finally, if our parameterization for $\mathrm{TA}^{0}$ is included (option d) the $\mathrm{NC}_{\mathrm{T}}{ }^{\text {eq } \pi}$ values are lower than those obtained with the GSS' 96 option, the difference ranging from $-26 \mu \mathrm{mol} \cdot \mathrm{kg}^{-1}$ at $2^{\circ} \mathrm{C}$ to $-2 \mu \mathrm{mol} \cdot \mathrm{kg}^{-1}$ at $15^{\circ} \mathrm{C}$.

Briefly, at $2^{\circ} \mathrm{C}$ the inclusion of water vapor pressure in calculating $\mathrm{pCO}_{2}{ }^{\pi}$, the use of Mehrbach et al. (1973) constants, and our new $\mathrm{TA}^{0}$ parameterization independently reduce $\mathrm{NC}_{\mathrm{T}}{ }^{\mathrm{eq} \pi}$ by $-6,-8$ and $-12 \mu \mathrm{mol} \cdot \mathrm{kg}^{-1}$, respectively, whereas at $15^{\circ} \mathrm{C}$ the corresponding contributions are -10 , $+6,+2 \mu \mathrm{mol} \cdot \mathrm{kg}^{-1}$. Hence, GSS'96 greatly overestimate $\mathrm{NC}_{\mathrm{T}}{ }^{\mathrm{eq} \pi}$ and consequently $\mathrm{C}_{\mathrm{T}}{ }^{\mathrm{eq} \pi}$ in deep waters.

\section{CASE STUDY: REVALUATION OF $\mathrm{C}_{\mathrm{ANT}}$ ALONG THE OacesNAtIIIB-93 LINE.}

Using the OacesNAtlIIB-93 data we calculated $\mathrm{C}_{\mathrm{ANT}}$ from equation 5 , with our new approach for $\mathrm{TA}^{0}$ (equations 10 and 12) and option (d) for estimating $\mathrm{C}_{\mathrm{T}}{ }^{\mathrm{eq} \pi} \cdot \mathrm{R}_{\mathrm{N}}$ and $\mathrm{R}_{\mathrm{C}}$ are respectively equal to 10.6 and 1.45 according to Anderson and Sarmiento (1994). In addition, we calculated the apparent age of each water sample from the equilibrium partial pressure of $\mathrm{CFC}_{11}$ $\left(\mathrm{pCFC}_{11}\right)$ based on the solubility function of Warner and Weiss (1985) and the reconstructed 
history of atmospheric $\mathrm{pCFC}_{11}$ from Walker et al. (2000) as described by Bullister (1984) and Doney and Bullister (1992).

The $\Delta \mathrm{C}_{\mathrm{Tdis}}$ is evaluated by density intervals as in GSS'96, here explained in the Formulation section (equations 7 and 8). Some of the assumptions used by GSS'96 in the calculation of the former term are the following: first of all, that the $\Delta \mathrm{C}_{\text {Tdis }}$ has remained constant over time and that tracer age is equal to the true water age. The first assumption has recently been verified by the analysis of $\mathrm{CO}_{2}$ time-series data, showing that surface seawater $\mathrm{CO}_{2}$ has kept pace with the atmospheric $\mathrm{CO}_{2}$ increase (Bates et al., 1996; Bates, 2001; Feely et al., 1999) over the last four decades. The second assumption holds true for tritium- ${ }^{3} \mathrm{He}$ ages, as explained by GSS'96 and Gruber (1998), if the transport is mainly advective. In the case of CFCs, true age equals CFC age if the water parcel was saturated with $\mathrm{CFC}$ in the formation area and if mixing is mainly along isopycnals, without mixing between waters with significantly different CFC concentrations. In this case, the age method (equation 8) is used for surfaces lighter than $\sigma_{4}=45.81 \mathrm{~kg} \cdot \mathrm{m}^{-3}$, which have a $\mathrm{CFC}_{11}$ concentration higher than $0.1 \mathrm{pM} \cdot \mathrm{kg}^{-1}$.

The $\Delta \mathrm{C}_{\mathrm{Tdis}}$ by density intervals is shown in Table 2 in terms of carbon and $\mathrm{pCO}_{2}$, along with the mean depth and $\mathrm{CFC}_{11}$ age. Density layers with $\sigma_{2} \leq 36.5 \mathrm{~kg} \cdot \mathrm{m}^{-3}$ have a $\mathrm{CFC}_{11}$ age lower than 15 years. Up to this age, according to Doney et al. (1997), CFC-derived and corrected tritium- ${ }^{3} \mathrm{He}$ ages are linearly related with a small positive offset of 1-2 years in the CFC ages. Despite this, both tracers are good estimators for the ideal ventilation age in the main thermocline (Thiele and Samiento, 1990). A recent study compares CFC and ideal ages obtained from a simple, highly idealised model of the CFC uptake in the thermocline (Sonnerup, 2001) and concludes that CFC ages less than 15 years agree with the ideal age being to within $25 \%$. CFC ages older than 15 years are significantly higher than the corrected tritium- ${ }^{3} \mathrm{He}$ ages, and both diverge from the ideal ventilation time-scales (Doney et al., 1997; Sonnerup, 2001). The more rapid exchange rate for ${ }^{3} \mathrm{He}$ and the non-linear mixing effects at greater tracer ages are the most likely reasons for this discrepancy.

Surface layers with $\sigma_{\theta} \leq 27 \mathrm{~kg} \cdot \mathrm{m}^{-3}$ tend to be slightly undersaturated, and waters from $\sigma_{\theta}=$ $27.1 \mathrm{~kg} \cdot \mathrm{m}^{-3}$ to $\sigma_{2}=36.5 \mathrm{~kg} \cdot \mathrm{m}^{-3}$ are slightly oversaturated in $\mathrm{CO}_{2}$. These results contrast with those from GSS'96: their $\Delta \mathrm{C}_{\text {Tdis }}$ range from -22 to $-16 \mu \mathrm{mol} \cdot \mathrm{kg}^{-1}$ and from -30 to $-20 \mu$ atm in $\mathrm{pCO}_{2}$. The deepest layers, where no $\mathrm{C}_{\mathrm{ANT}}$ contamination is expected, present a small positive disequilibrium (about $4 \mu \mathrm{mol} \cdot \mathrm{kg}^{-1}$ and $5 \mu \mathrm{atm}$, Table 2), in contrast with the negative values proposed by GSS'96 (-16 $\mu \mathrm{mol} \cdot \mathrm{kg}^{-1}$ and $\left.-33 \mu \mathrm{atm}\right)$ or the strong negative $\Delta \mathrm{C}_{\text {Tdis }}$ obtained by Wanninkhof et al. (1999a) $\left(-40 \mu \mathrm{mol} \cdot \mathrm{kg}^{-1}\right)$. Intermediate layers also present low and negative $\Delta \mathrm{C}_{\text {Tdis }}$ values, smaller than those obtained by GSS'96 and Wanninkhof et al. (1999a).

The aforementioned comments about the $\Delta \mathrm{C}_{\text {Tdis }}$ estimation method and assumptions combined with our results lead us to doubt the existence of a significant air-sea disequilibrium 
term. In the main thermocline where the apparent age approximates true age with a high degree of reliability, the mean $\Delta \mathrm{C}_{\text {Tdis }}$ is $0 \pm 5 \mu \mathrm{mol} \cdot \mathrm{kg}^{-1}$. At intermediate levels we also obtained low disequilibrium values. However, they are subject to a greater uncertainty in the estimation of the age as mentioned previously. Thus, we disregard these results in our analysis. At the deepest density intervals, where no significant anthropogenic $\mathrm{CO}_{2}$ signal is expected, the $\Delta \mathrm{C}_{\text {Tdis }}$ values are very low as well $\left(3 \pm 1 \mu \mathrm{mol} \cdot \mathrm{kg}^{-1}\right)$, and in agreement with the low values obtained in the main thermocline layer.

Figure 5 shows the relationship between $\Delta \mathrm{C}^{*}(\tau)$ calculated with our improvements and that applying GSS'96 against the apparent $\mathrm{CFC}_{11}$ age. The inset in Figure 5 shows both $\Delta \mathrm{C}^{*}(\tau)$ but against depth. The mean $\Delta \mathrm{C}^{*}(\tau)$ for the upper $200 \mathrm{~m}$ are $41 \pm 3$ and $45 \pm 4 \mu \mathrm{mol} \cdot \mathrm{kg}^{-1}$ from GSS'96 and this work, respectively, and the corresponding means below $3500 \mathrm{~m}$ are $-13 \pm 2$ and $4 \pm 3$ $\mu \mathrm{mol} \cdot \mathrm{kg}^{-1}$. GSS'96 gives disequilibria of -12 and $-16 \mu \mathrm{mol} \cdot \mathrm{kg}^{-1}$ for the upper and deep layers, respectively. Thus, the $\mathrm{C}_{\mathrm{ANT}}$ according to GSS'96 for these two layers would be $53 \pm 3$ and $3 \pm 2$ $\mu \mathrm{mol} \cdot \mathrm{kg}^{-1}$. Neglecting the $\mathrm{CO}_{2}$ disequilibrium, our $\mathrm{C}_{\mathrm{ANT}}$ would be $45 \pm 4$ and $4 \pm 3 \mu \mathrm{mol} \cdot \mathrm{kg}^{-1}$.

The expected increase in surface $\mathrm{C}_{\mathrm{T}}$ up to 1993 is $50 \mu \mathrm{mol} \cdot \mathrm{kg}^{-1}$, estimated from TA ${ }^{0}$ (a mean value of $2330 \mu \mathrm{mol} \cdot \mathrm{kg}^{-1}$ at $15^{\circ} \mathrm{C}$ and salinity of 35) and the atmospheric $\mathrm{pCO}_{2}$ increase. Given the uncertainty in the back-calculation method for estimating $\mathrm{C}_{\mathrm{ANT}}$ the previous theoretical increase agrees with the calculated $\mathrm{C}_{\mathrm{ANT}}$ according to GSS'96 $\left(53 \pm 3 \mu \mathrm{mol} \cdot \mathrm{kg}^{-1}\right)$ and this work $(45 \pm 4$ $\left.\mu \mathrm{mol} \cdot \mathrm{kg}^{-1}\right)$. Correspondingly, in deeper layers where an insignificant anthropogenic $\mathrm{CO}_{2}$ concentration is expected, both estimations of $\mathrm{C}_{\mathrm{ANT}}$ agree, $3 \pm 2$ and $4 \pm 3 \mu \mathrm{mol} \cdot \mathrm{kg}^{-1}$ from GSS'96 and this work, respectively.

These results could be misleading, as both methods, that developed by GSS'96 and the improvements proposed here, yield the same quantities at particular deep layers, but start from divergent assumptions. We arise the question about the existence of a significant air-sea disequilibrium term.

\section{DISCUSSION.}

The back-calculation technique for estimating anthropogenic $\mathrm{CO}_{2}$ introduced by Chen and Millero (1979) and Brewer (1978) and recently reviewed by GSS'96, was developed on the same principles as the conservative parameters NO or CAO (Broecker, 1974; Ríos et al., 1989). The work by GSS' 96 renewed the attention on estimating the $\mathrm{C}_{\mathrm{ANT}}$ inventory in the ocean as a way to constrain global ocean circulation and biogeochemical models. The GSS'96 procedure suffers from some sources of error, among which we have evaluated the most important: the estimation of $\mathrm{TA}^{0}$, the effect of water vapor pressure on calculating pre-industrial $\mathrm{pCO}_{2}$ and the $\mathrm{CO}_{2}$ dissociation constants. Their impact on $\Delta C^{*}(\tau)$ is of great significance, especially in deep waters where errors in 
the preformed estimates can lead to anomalous values, which GSS'96 ascribed to a disequilibrium term.

$\mathrm{TA}^{0}$ has been generally parameterised as an empirical function of conservative parameters in order to correct for mixing effects and biological activity. Despite its being a very reasonable approximation, the lack of wintertime measurements of surface TA prevents it from being put into practice. Most of the oceanic $\mathrm{CO}_{2}$ data have been collected in summer or spring, when seasonal warming, phytoplankton activity and oxygen outgassing take place. Therefore, temperatureparameterised $\mathrm{TA}^{0}$ values are overestimated because of the shift to higher temperatures in the initial $\mathrm{TA}^{0}$ values. Moreover, using PO or NO does not counteract this effect because they do not correct for the oxygen outgassing. Empirical relations between high quality alkalinity data and salinity and other conservative parameters such as NO or PO obtained during wintertime in formation areas will be excellent for modelling the preformed alkalinity values. However, another potential procedure would be the analysis of data not affected by seasonal warming or freshwater flux variations, that is, data from the homogenous layer below the seasonal thermocline as an approximation for the winter mixed layer (e.g. Wanninkhof et al., 1999a and Körtzinger et al., 2001). Preformed alkalinity values obtained in this manner should also be consistent with the decomposition of organic and inorganic matter in the water column.

Recently, the dissociation constants by Mehrbach et al. (1973) have been confirmed to be the most suitable for calculating $\mathrm{C}_{\mathrm{T}}$ from $\mathrm{TA}$ and $\mathrm{pCO}_{2}$. This set of constants was the only one determined on natural seawater, thus including the interferences of all its acid-base components, even those derived from organic matter.

After applying our proposed improvements: the $\mathrm{TA}^{0}$ parameterization, including the water vapor effect on pre-industrial $\mathrm{pCO}_{2}$ calculation and using the Mehrbach et al. (1973) constants, we question the existence of a disequilibrium term as high as that concluded by GSS'96. From their point of view, this term is a "cul-de-sac" accumulating the air-sea disequilibrium in $\mathrm{CO}_{2}$, any residual effects due to the selection of the $\mathrm{TA}^{0}$ and oxygen end-members, as well as the uncertainty in data and parameters. In deep waters, this disequilibrium is an artefact to correct negative values of their $\Delta C^{*}(\tau)$ (our $\mathrm{C}_{\mathrm{ANT}}$ ) to zero where no anthropogenic contamination is expected, and originates mainly from an inaccurate estimation of the alkalinity pump and the set of constants used, and therefore the $\mathrm{C}_{\mathrm{T}}{ }^{\mathrm{eq} \pi}$. In the main thermocline, where the age uncertainty ( 2 years as maximum) is much lower that at depth, the $\Delta \mathrm{C}_{\text {Tdis }}$ proposed by GSS'96 (from -12 to -24 $\mu \mathrm{mol} \cdot \mathrm{kg}^{-1}$, corresponding to -19 to $-35 \mu \mathrm{atm}$ ) seems unrealistically high and would arise (equation 7) from the overestimation of $\mathrm{TA}^{0}$, affecting also the calculation of $\mathrm{C}_{\mathrm{T}}{ }^{\mathrm{eq}}\left(\theta, \mathrm{S}, \mathrm{TA}^{0}, \mathrm{pCO}_{2}{ }^{\top}\right)$, which is also affected by the choice of dissociation constants and the effect of water vapor pressure on $\mathrm{pCO}_{2}{ }^{\tau}$. Between very young and ancient water masses, the disequilibrium stems mainly from the 
bias towards younger ages of the tracer apparent ages (Beining and Roether, 1996; Doney et al., 1997; Sonnerup, 2001), leading to an overestimation of $\mathrm{pCO}_{2}{ }^{\tau}$ from the tracer age.

The non-existence of significant $\Delta \mathrm{C}_{\text {Tdis }}$ when the water masses are formed can be directly corroborated only with winter measurements of $\mathrm{CO}_{2}$ parameters on formation areas. Peng et al. (1987) reported seasonal variations of carbon dioxide, nutrients and oxygen in the Irminger Sea surface water from 1983 to 1985 , showing surface water nearly in equilibrium with atmospheric oxygen and $\mathrm{CO}_{2}$ during the winter months. Only their winter values with mixed layer depths exceeding $300 \mathrm{~m}$ are reproduced in Table $3 . \mathrm{C}_{\mathrm{T}}{ }^{0}(\tau)$ calculated as in equation 1 from $\mathrm{C}_{\mathrm{T}}$ and AOU minus $\mathrm{C}_{\mathrm{T}}{ }^{\mathrm{eq}}\left(\theta, \mathrm{S}, \mathrm{TA}^{0}, \mathrm{pCO}_{2}{ }^{\tau}\right)$ represent the $\Delta \mathrm{C}_{\mathrm{Tdis}}$ according to equation $2 . \Delta \mathrm{C}_{\mathrm{Tdis}}$ are slightly negative for the three isopycnals (from 0 to $-2 \mu \mathrm{mol} \cdot \mathrm{kg}^{-1}$ ), expressed in terms of $\mathrm{pCO}_{2}$ from 0 to -3 $\mu \mathrm{atm}$. In conclusion, wintertime measurements of $\mathrm{CO}_{2}$ and oxygen in the Irminger Sea point to the same degree of air-sea disequilibrium in both tracers, mutually compensated.

More recently, Takahashi et al. (1993) collected $\mathrm{CO}_{2}$ and nutrient data in high-latitude oceans in order to study their seasonal cycle. Around Iceland they found $\mathrm{pCO}_{2}$ air-sea gradients during winter months ranging from 10 to $-30 \mu \mathrm{atm}$, being about $-12 \mu \mathrm{atm}$ in the Eastern North Atlantic. No oxygen values were reported, but presumably these slight $\mathrm{CO}_{2}$ disequilibria are partially compensated by AOU during these short deep winter mixing events.

More evidence supports our proposal of a low level of disequilibrium. A completely independent and comprehensive data set was collected between $30^{\circ}$ and $60^{\circ} \mathrm{N}$ along $20^{\circ} \mathrm{W}$ during summer 1996, practically the same track as the OacesNAtlIIB-93 line. The high quality $\mathrm{CO}_{2}$ data collected is presented and analysed in Körtzinger et al. (2001). Following a procedure described in Takahashi et al. (1985) they calculated the wintertime $\mathrm{C}_{\mathrm{T}}$ concentrations by isopycnals (Table 3 ). $\mathrm{C}_{\mathrm{T}}$ once biologically corrected, $\mathrm{C}_{\mathrm{T}}^{0}(\tau)$, practically corresponds with $\mathrm{C}_{\mathrm{T}}{ }^{\text {eq }}$ in $1996 . \Delta \mathrm{C}_{\mathrm{Tdis}}$ ranges from -5 to $2 \mu \mathrm{mol} \cdot \mathrm{kg}^{-1}$, in $\mathrm{pCO}_{2}$ terms from -9 to $3 \mu \mathrm{atm}$, supporting our assumption of a negligible $\mathrm{CO}_{2}$ disequilibrium.

Labrador sea data taken in July-August 1996, kindly provided by Mintrop and Körtzinger (CARINA web page, http://www.ifm.uni-kiel.de/ch/carina/index.htm), also support our proposal of a small air-sea disequilibrium when water masses are formed. $\mathrm{CO}_{2}$ and oxygen data were selected to characterise an homogenous layer of Labrador Sea Water (LSW) (from 200 to $1800 \mathrm{~m}$ ), whose mean and standard deviation characteristics are shown in Table 3. The mean age of this homogenous layer was $9 \pm 2$ years, estimated from $\mathrm{CFC}_{11}$, giving $\mathrm{C}_{\mathrm{T}}{ }^{0}(\tau)$ very close to $\mathrm{C}_{\mathrm{T}}{ }^{\mathrm{eq}}(\theta, \mathrm{S}$, $\mathrm{TA}^{0}, \mathrm{pCO}_{2}{ }^{\tau}$ ) (Table 3). The analysis of this data reinforces our concept of the same degree of airsea disequilibrium in oxygen and $\mathrm{CO}_{2}$, and even $\mathrm{CFC}_{11}$, when water masses are formed, resulting in a negligible effective $\mathrm{CO}_{2}$ disequilibrium. This means that the three gases $\left(\mathrm{CO}_{2}, \mathrm{O}_{2}, \mathrm{CFC}_{11}\right)$ were at the same degree of air-sea disequilibrium when the LSW was last in contact with the atmosphere. 
The calculated disequilibrium stems mainly from the mixing between newly formed vintages of LSW and those ventilated in the preceding winters.

GSS'96 showed a good latitudinal correlation between $\Delta \mathrm{pCO}_{2}$ estimated from their $\Delta \mathrm{C}_{\mathrm{Tdis}}$ and winter zonal $\Delta \mathrm{pCO}_{2}$ mean values given by Takahashi et al. (1997). The strong natural $\Delta \mathrm{pCO}_{2}$ at northern latitudes derives from surface cooling. In this connection, remember the strong bias of $\Delta \mathrm{C}_{\text {Tdis }}$ toward low values at low temperatures due to inaccuracies in the back-calculation technique. The effective $\Delta \mathrm{C}_{\text {Tdis }}$ would be set when water looses its contact with the atmosphere, reaching maximum winter mixing depths under very severe weather conditions. Although under these strong wind conditions the air-sea exchange is strongly enhanced (Nightingale et al., 2000; Wanninkhof and McGillis, 1999), rapid deep mixing with underlying $\mathrm{CO}_{2}$-loaden and oxygen poor waters also takes place, finally resulting in a winter mixed layer slightly oversaturated in $\mathrm{CO}_{2}$ and undersaturated in oxygen (see Table 3). These conditions take place in late winter or early spring. Presumably zonal averages of winter $\Delta \mathrm{pCO}_{2}$ values are not representative of $\Delta \mathrm{pCO}_{2}$ when the water mass looses contact with atmosphere. Furthermore, the outcrop of water masses is a spatially localised phenomenon, occurring at specific areas where the stability of the surface layer is reduced. So, we think the agreement between mean zonal $\Delta \mathrm{pCO}_{2}$ from GSS'96 and Takahashi et al. (1997) is somehow spurious and fortuitous.

In summary, we showed evidence for some significant deficiencies in the estimation of the anthropogenic $\mathrm{CO}_{2}$ uptake in the oceans. The estimation of $\mathrm{TA}^{0}$ as a function of AOU and IOR, the addition of water vapor pressure in the calculation of pre-industrial $\mathrm{pCO}_{2}$ and the selection of the appropriate carbonic acid dissociation constants (Merhbach et al., 1973) stand out as key factors in the back-calculation technique for $\mathrm{C}_{\mathrm{ANT}}$. These improvements yielded consistent results in the estimation of $\mathrm{C}_{\mathrm{ANT}}$ along a section in the Eastern North Atlantic Ocean, with practically no anthropogenic input in deep and bottom waters and reasonable $\mathrm{C}_{\mathrm{ANT}}$ concentrations in the upper water column. We conclude that there does not exist a significant $\mathrm{CO}_{2}$ disequilibrium when water masses are formed, previous claims of such a disequilibrium being based on an artefact arising from the inaccuracy in estimating preformed $\mathrm{TA}^{0}$, pre-industrial equilibrium $\mathrm{C}_{\mathrm{T}}$ and the water masses true age, which is estimated from transient tracers.

Our improvements on $\mathrm{C}_{\mathrm{ANT}}$ can be applied for any other ocean basin, except for the parameterization of $\mathrm{TA}^{0}$, which is specific for the North Atlantic Ocean. Similar procedures for other ocean basins where long-term average rain ratios are available could be developed. Despite the proposed improvements, uncertainties still remain in the estimation of $\mathrm{C}_{\mathrm{ANT}}$ : the respiratory quotient for sinking organic matter, the mixing problem, but overall the verification of preformed values of oxygen, alkalinity, $\mathrm{pCO}_{2}$ and nutrients at the winter mixed layer. 


\section{Acknowledgments.}

This work would not have been possible without the effort of the scientists collecting and distributing the $\mathrm{CO}_{2}$ data during the OACES program in the North Atlantic carried out by the NOAA Atlantic Oceanographic and Meteorological Laboratory (AOML) and the Pacific Marine Environmental Laboratory (PMEL). Our special thanks to the Oak Ridge Carbon Dioxide Information Analysis Center (CDIAC) and the CARbon dioxide In the North Atlantic (CARINA) program for providing high-quality $\mathrm{CO}_{2}$ data sets to the research community. M. Álvarez was financed by the "Xunta de Galicia" with a predoctoral grant. This work was supported by grant number CICYT-MAR97-0660. Constructive comments by two anonymous reviewers helped to improve the manuscript. We thank Dr. M. Bacon for his editorial comments. 


\section{REFERENCES.}

Anderson, L.A., Sarmiento, J.L., 1994. Redfield ratios of remineralization determined by nutrient data analysis. Global Biogeochemical Cycles 8, 65-80.

Bates, N.R., Michaels, A.F., Knap, A.H., 1996. Seasonal and interannual variability of oceanic carbon dioxide species at the U.S. JGOFS Bermuda Atlantic Time-series Study (BATS) site. Deep-Sea Research II 43, 347-383.

Bates, N.R., 2001. Interannual variability of oceanic $\mathrm{CO}_{2}$ and biogeochemical properties in the Western North Atlantic Subtropical gyre. Deep-Sea Research II 48, 1507-1528.

Beining, P., Roether, W., 1996. Temporal evolution of CFC-11 and CFC-12 concentrations in the ocean interior. Journal of Geophysical Research 101, 16455-16464.

Berger, W.H., Herguera, J.C., 1992. Reading the sedimentary record of the ocean's productivity. In: Primary Productivity and Biogeochemical Cycles in the Sea. Edited by P.G. Falkowski and A.D. Woodhead, Plenum Press, New York.

Brewer, P.G., 1978. Direct observations of the oceanic $\mathrm{CO}_{2}$ increase. Geophysical Research Letters $5,997-1000$.

Brewer, P.G., Bradshaw, A., Williams, R., 1986. Measurements of total carbon dioxide and alkalinity in the North Atlantic Ocean in 1981, in the Changing Carbon Cycle, A Global Analysis, edited by J. Trabalka and D. Reichle, pp. 358-381, Springer-Verlag, New York.

Brewer, P.G., Glover, D.M., Goyet, C. and Shafer, D.K., 1995. The pH of the North Atlantic Ocean: Improvements to the global model for sound absorption in seawater. Journal of Geophysical Research, 100, 8761-8776.

Broecker, W.S., Peng, T.-H., 1982. Tracers in the Sea. Columbia University. Eldigio Press. New York, $690 \mathrm{pp}$.

Broecker, W.S., 1974. "NO" a conservative water mass tracer. Earth Planetary Science Letters 23, 100-107.

Bullister, J.L., 1984. Atmospheric chlorofluoromethanes as tracers of ocean circulation and mixing: measurements and calibration techniques and studies in the Greenland and Norwegian Seas. Ph.D. Thesis, Univ. Of California, San Diego, La Jolla, 172 pp.

Chen, C.-T., Pytkowicz, R.M., 1979. On the total $\mathrm{CO}_{2}$-titration alkalinity-oxygen system in the Pacific Ocean. Nature 281, 363-365.

Chen, C.T., 1982. On the distribution of anthropogenic $\mathrm{CO}_{2}$ in the Atlantic and Southern oceans. Deep-Sea Research 29, 563-580.

Chen, C.T., Millero, F.J., 1979. Gradual increase of oceanic carbon dioxide. Nature 277, 205-206.

Chen,C.T., Jones, E.P., Lin, K., 1990. Wintertime total carbon dioxide measurements in the Norwegian and Greenland Sea. Deep-Sea Research 9, 1455-1473. 
DOE Handbook, 1994. Handbook of methods for the Analysis of the Various Variables of the Carbon Dioxide System in Seawater; v.2, A.G. Dickson and C. Goyet (Eds.) ORNL/CDIAC74.

Doney, S.C., Bullister, J.L., 1992. A chlorofluorocarbon section in the eastern North Atlantic. Deep-Sea Research 39, 1857-1883.

Doney, S.C., Jenkins, W.J., Bullister, J.L., 1997. A comparison of ocean tracer dating techniques on a meridional section in the eastern North Atlantic. Deep-Sea Research I 44, 603-626.

Feely, R.A., Wanninkhof, R., Takahashi, T., Tans, P., 1999. Influence of El Niño on the equatorial Pacific contribution to atmospheric $\mathrm{CO}_{2}$ accumulation. Nature 398, 597-601.

Goyet, C., Poisson, A., 1989. New determination of carbonic acid dissociation constants in seawater as a function of temperature and salinity. Deep-Sea Research 36, 1635-1654.

Gruber, N, 1998. Anthropogenic $\mathrm{CO}_{2}$ in the Atlantic ocean. Global Biogeochemical Cycles 12, 165-191.

Gruber, N., Sarmiento, J.L, Stocker, T.F., 1996. An improved method for detecting anthropogenic $\mathrm{CO}_{2}$ in the oceans. Global Biogeochemical Cycles 10, 809-837.

Honjo, S., Manganini, S.J., 1993. Annual biogenic particle fluxes to the interior of the North Atlantic Ocean; studied at $34^{\circ} \mathrm{N} 21^{\circ} \mathrm{W}$. Deep-Sea Research 40, 587-607.

Honjo, S., Manganini, S.J., Cole, J.J., 1982. Sedimentation of biogenic matter in the deep ocean. Deep-Sea Research I 29, 609-625.

Huang, R. X., 1989. On the three-dimensional structure of the wind-driven circulation in the North Atlantic. Dynamics of Atmosphere and Oceans 15, 117-159.

Johnson, K.M., Körtzinger, A., Mintrop, L., Duinker, J.C., Wallace, D.W.R., 1999. Coulometric total carbon dioxide analysis for marine studies: measurement and internal consistency of underway $\mathrm{TCO}_{2}$ concentrations. Marine Chemistry 67, 123-144.

Körtzinger, A., Koeve, W., Kähler, P., Mintrop, L., 2001. C:N ratios in the mixed layer during the productive season in the northeast Atlantic Ocean. Deep-Sea Research I 48, 661-688.

Körtzinger, A., Mintrop, L., Duinker, J.C., 1998. On the penetration of anthropogenic $\mathrm{CO}_{2}$ into the North Atlantic Ocean. Journal of Geophysical Research 103, 18681-18689.

Lee, K., Millero, F.J., Byrne, R., Feely, R. A., Wanninkhof, R., 2000. The recommended dissociation constants for carbonic acid in seawater. Geophysical Research Letters 27, 229232,2000 .

Marshall, J.C., Nurser, A.J.G., Williams, R.G., 1993. Inferring the subduction rate and period over the North Atlantic. Journal of Physical Oceanography 23, 1315-1329.

Martin, J. H., Fitzwater, S.E., Gordon, R.M., Hunter, C.N., Tanner, S.J., 1993. Iron, primary production and carbon-nitrogen flux studies during the JGOFS North Atlantic Bloom Experiment. Deep-Sea Research II 40, 641-653. 
Mehrbach, C., Culberson, C.H., Hawley, J.E., Pytkowicz, R.M., 1973. Measurements of the apparent dissociation constant of carbonic acid in seawater at atmospheric pressure. Limnology and Oceanography 8, 897-907.

Millero, F.J., Lee, K., Roche, M., 1998. Distribution of alkalinity in the surface waters of the major oceans. Marine Chemistry 60, 95-110.

Milliman, J.D., Troy, P.J., Bakch, W.M., Adams, A.K., Li, Y.-H., Mackenzie, F.T., 1999. Biologically mediated dissolution of calcium carbonate above the chemical lysocline?. DeepSea Research I 46, 1653-1669.

Mintrop, L., Körtzinger, A., Duinker, J.C., 1999. The carbon dioxide system in the northwestern Indian Ocean during south-west monsoon. Marine Chemistry 64, 315-336.

Mintrop, L., Pérez, F.F., González-Dávila, M., Santana-Casiano, J.M., Körtzinger, A., 2000. Alkalinity determination by potentiometry: intercalibration using three different methods. Ciencias Marinas 26, 23-37.

Neftel, A., Friedli, H., Moor, E., Lötscher, H., Oeschger, H., Siegenthaler, U., Stauffer B., 1994. Historical $\mathrm{CO}_{2}$ record from the Siple station ice core, in Trends'93: A compendium of Data on Global Change, edited by T. Boden, D. Kaiser, R. Sepanski, and F. Stoss, Rep. ORNL/CDIAC-65 pp.11-14, Carbon Dioxide Inf. Anal. Cent., Oak Ridge Nath. Lab., Oak Ridge, Tenn.

Newton, P.P., Lampitt, R.S., Jickells, T.D., King, P., Boutle, C., 1994. Temporal and spatial variability of biogenic particle fluxes during the JGOFS Northeast Atlantic process studies at $47^{\circ} \mathrm{N}, 20^{\circ} \mathrm{W}$. Deep-sea Research 41, 1617-1642.

Nightingale, P.D., Malin, G., Law, C.S., Watson, A.J., Liss, P.S., Liddicoat, M.I., Boutin, J., Upstill-Goddard, R.C. 2000. In situ evaluation of air-sea gas exchange parameterizations using novel conservative and volatile tracers. Global Biogeochemical Cycles 14, 373-387.

Peng, T.-H., Takahashi, T., Broecker, W.S., 1987. Seasonal variability of carbon dioxide, nutrients and oxygen in the northern North Atlantic surface water: observations and a model. TellusB $39,439-458$.

Ríos, A.F., Pérez, F.F., 1999. Improvements in potentiometric determinations of the $\mathrm{CO}_{2}$ oceanic system using seawater substandards and $\mathrm{CO}_{2}$ reference material. Ciencias Marinas 25, 31-49.

Ríos, A.F., Álvarez-Salgado, X.A., Pérez, F.F., Bingler, L.S., Arístegui, J., Mémery, L., 2001. Carbon dioxide along WOCE line A14: internal consistency, water masses characterization and anthropogenic entry. Journal of Geophysical Research, under revision.

Ríos, A.F., Anderson, T.R., Pérez, F.F., 1995. The carbonic system distribution and fluxes in the NE Atlantic during Spring 1991. Progress in Oceanography 35, 295-314.

Ríos, A.F., Fraga, F., Pérez, F.F., 1989. Estimation of coefficients for the calculation of "NO", "PO" and "CO", starting from the elemental composition of natural phytoplankton. Scientia Marina 53, 779-784. 
Sabine, C.L., Key, R.M., Johnson, K.M., Poisson, A., Sarmiento, J.L., Wallace, D.W.R., Winn, C.D., 1999. Anthropogenic $\mathrm{CO}_{2}$ inventory of the Indian Ocean. Global Biogeochemical Cycles 13, 179-198.

Sarmiento, J.L., Murnane, R., Quere, C. Le, 1995. Air-sea $\mathrm{CO}_{2}$ transfer and the carbon budget of the North Atlantic. Philosophical Transactions of the Royal Society of London 348, 211219.

Siegenthaler, U, Sarmiento, J., 1993. Atmospheric carbon dioxide and the ocean. Nature 365, 119125.

Sonnerup, R.E., 2001. On the relations among CFC derived water mass ages. Geophysical Research Letters, 28, 1739-1742.

Tait, V.K., Gershey, R.M., Jones, E.P. 2000. Inorganic carbon in the Labrador Sea: Estimation of the anthropogenic component. Deep-Sea Research I 47, 295-308.

Takahashi, T., Broecker, W.S., Brainbridge, A.E., 1981. The alkalinity and total carbon dioxide concentration in the world ocean, in Carbon Cycle Modelling, edited by B. Bolin, pp. 271286, SCOPE col. 16, John Wiley, New York.

Takahashi, T., Broecker, W.S., Langer, S., 1985. Redfield ratio based on chemical data from isopycnal surfaces. Journal of Geophysical Research 90, 6907-6924.

Takahashi, T., Feely, R.A., Weiss, R.F., Wanninkhof, R.H., Chipman, D.W., 1997. Global air-sea flux of $\mathrm{CO}_{2}$ : An estimate based on measurements of sea-air $\mathrm{pCO}_{2}$ difference. Proceedings of the National Academy of Sciences 94, 8292-8299.

Takahashi, T., Olafsson, J., Goddard, J.G., Chipman, D.W., Sutherland, S.C., 1993. Seasonal variation of $\mathrm{CO}_{2}$ and nutrients in the high-latitude surface oceans: a comparative study. Global Biogeochemical Cycles 7, 843-878.

Tapp, M., Hunter, K., Currie, K., Mackaskill, B., 2000. Apparatus for continuous-flow underway spectrophotometric measurement of surface water pH. Marine Chemistry 72, 193-202.

Thiele, G, Sarmiento, J.L., 1990. Tracer dating and ocean ventilation. Journal of Geophysical Research 95, 9377-9391.

Thomas, H., Ittekkot, V. 2001. Determination of anthropogenic $\mathrm{CO}_{2}$ in the North Atlanic Ocean using water mass ages and $\mathrm{CO}_{2}$ equilibrium chemistry. Journal of Marine Systems 27, 325336.

Tréguer, P., Nelson, D.M., van Bennekom, A.J., DeMaster, D.J., Laynaert, A., Quéguiner, B. 1995. The silicate balance in the world ocean: A reestimate. Science, 268, 375-379.

UNESCO, 1986. Progress on Oceanographic Tables and Standards 1983-1986. Work and recommendations of the UNESCO/SCOR/ICES/IAPSO Joint Panel. UNESCO Technical Papers in Marine Science, 50.

Volk, T., Hoffert, M.I., 1985. Ocean carbon pumps: analysis of relative strengths and efficiencies in ocean -driven atmospheric $\mathrm{CO}_{2}$ changes. In: The Carbon Cycle and Atmospheric $\mathrm{CO}_{2}$ : 
Natural Variations Archean to Present, Geophys. Monogr. Ser., vol. 32, edited by E.T. Sundquist and W.S. Broecker, pp. 99-110, AGU, Washington, D.C., 1985.

Walker, S.J., Weiss, R.F., Salameh, P.K., 2000. Reconstructed histories of the annual mean atmospheric mole fractions for the halocarbons CFC-11, CFC-12, CFC-113 and carbon tetrachloride. Journal of Geophysical Research 105, 14285-14296.

Wanninkhof, R., McGillis, W.R., 1999. A cubic relationship between air-sea $\mathrm{CO}_{2}$ exchange and wind speed. Geophysical Research Letters 26, 1889-1892.

Wanninkhof, R., Thoning, K., 1993. Measurements of fugacity of $\mathrm{CO}_{2}$ in surface water using continuous and discrete sampling methods. Marine Chemistry 44, 189-204.

Wanninkhof, R., Doney, S.C., Peng, T.H., Bullister, J.L., Lee, K., Feely, R.A., 1999a. Comparison of methods to determine the anthropogenic $\mathrm{CO}_{2}$ invasion into the Atlantic Ocean. Tellus 51B, 511-530.

Wanninkhof, R., Lewis, E., Feely, R.A., Millero, F.J., 1999b. The optimal carbonate dissociation constants for determining surface water $\mathrm{pCO}_{2}$ from alkalinity and total inorganic carbon. Marine Chemistry 65, 291-301.

Warner, M.J., Weiss, R.F., 1985. Solubilities of chlorofluorocarbons 11 and 12 in water and sea water. Deep-Sea Research 32, 1485-1497, 1985.

Watson, A.J., Nightingale, P.D., Cooper, D.J., 1995. Modelling atmosphere-ocean $\mathrm{CO}_{2}$ transfer. Philosophical Transaction of the Royal Society of London 348, 125-132.

Yu, E.-F., Francois, R., Bacon, M.P., Honjo, S., Fleer, A.P., Manganini, S.J., Rutgers van der Loeff, M.M., Ittekot, V. 2001. Trapping efficiency of bottom-tethered sediment traps estimated from the intercepted fluxes of ${ }^{230} \mathrm{Th}$ and ${ }^{231} \mathrm{~Pa}$. Deep Sea Research I 48, 865-889. 


\section{FIGURE CAPTIONS.}

Figure 1. Relationship between dissolution of opal $\left(\Delta \mathrm{Si}=\mathrm{Si}-\mathrm{Si}^{0}\right.$ in $\left.\mu \mathrm{mol} \cdot \mathrm{kg}^{-1}\right)$ and carbonate $\left(\Delta \mathrm{TA}=\mathrm{TA}-\mathrm{TA}^{0}\right.$ in $\left.\mu \mathrm{mol} \cdot \mathrm{kg}^{-1}\right) . \mathrm{Si}^{0}$ has been calculated from equation 11 , and $\mathrm{TA}^{0}$ from GSS'96 (open squares, $\mathrm{TA}^{0}=367.5+54.9 \cdot \mathrm{S}+0.074 \cdot \mathrm{PO}$, where $\mathrm{S}$ is salinity and $\mathrm{PO}=$ 170 $\cdot \mathrm{PO}_{4}+\mathrm{O}_{2}$ ), Millero et al. (1998) (dark squares, $\mathrm{TA}^{0}=\mathrm{S} / 35 \cdot[2291-2.69 \cdot(\theta-20)$ $\left.0.046 \cdot(\theta-20)^{2}\right]$, where $\theta$ is temperature and $\mathrm{S}$ salinity), Wanninkhof et al. (1999b) (open circles, $\mathrm{TA}^{0}=278.4+57.91 \cdot \mathrm{S}+0.0074 \cdot \mathrm{NO}$, where $\mathrm{S}$ is salinity and $\mathrm{NO}=10.6 \cdot \mathrm{NO}_{3}+\mathrm{O}_{2}$ ) and our new parametrization from equations 10 and 12 (dark circles).

Figure 2. Inorganic to Organic carbon decomposition Ratio (IOR) versus depth. IOR was calculated from equation 9 with $\mathrm{TA}^{0}$ from GSS'96 (open squares) and $\mathrm{TA}^{0}$ as a function of the opal dissolution (dark circles) $\left(\Delta \mathrm{TA}=1.42 \cdot \Delta \mathrm{Si}, \Delta \mathrm{Si}=\mathrm{Si}^{-\mathrm{Si}^{0}}\right.$, where $\mathrm{Si}^{0}$ has been calculated from equation 11). The solid line is the polynomial fit for the previous IOR data, as expressed in equation 12 .

Figure 3. Measured (dotted line) and modeled (solid line) profiles of organic (circles) and inorganic (squares) carbon fluxes at the NABE site. The inorganic carbon flux calculated based on TA $^{0}$ from GSS'96 is also shown (crosses). Note the reversed scale for the inorganic carbon flux axis.

Figure 4. Salinity-normalized pre-industrial equilibrium total inorganic carbon $\left(\mathrm{C}_{\mathrm{T}}{ }^{\mathrm{eq} \pi}\right.$ in $\left.\mu \mathrm{mol} \cdot \mathrm{kg}^{-1}\right)$ versus potential temperature $\left(\theta\right.$ in $\left.{ }^{\circ} \mathrm{C}\right)$ based on different approximations. Dark squares (option a, see text) stand for $\mathrm{C}_{\mathrm{T}}{ }^{\text {eq } \pi}$ calculated with $\mathrm{TA}^{0}$ from GSS'96, a constant value for pre-industrial $\mathrm{pCO}_{2}$ of $280 \mu \mathrm{atm}$ and the Goyet and Poisson (1989) constants. Open circles (option b) denote $\mathrm{C}_{\mathrm{T}}{ }^{\text {eq } \pi}$ calculated with $\mathrm{TA}^{0}$ from GSS'96, pre-industrial $\mathrm{pCO}_{2}$ calculated as a function of a molar fraction of $278.2 \mathrm{ppm}$ and water vapor pressure (WV) and the constants of Goyet and Poisson (1989). Crosses (option c) indicate $\mathrm{C}_{\mathrm{T}}{ }^{\mathrm{eq} \pi}$ calculated the same as before but with the Mehrbach et al. (1973) constants (Mehr). Dark circles (option d) represent $\mathrm{C}_{\mathrm{T}}{ }^{\text {eq } \pi}$ calculated with $\mathrm{TA}^{0}$ obtained from our equations 10 and 12 , pre-industrial $\mathrm{pCO}_{2}$ calculated as a function of a molar fraction of $278.2 \mathrm{ppm}$, water vapor pressure and the Mehrbach et al. (1973) constants (New approach). 
Figure 5. $\Delta \mathrm{C}^{*}(\tau)$ (in $\mu \mathrm{mol} \cdot \mathrm{kg}^{-1}$ ) calculated according to GSS'96 (open circles) and our improvements on the back-calculation technique (black circles) versus $\mathrm{CFC}_{11}$ age in years. The inset shows both $\Delta \mathrm{C}^{*}(\tau)$ versus depth. $\Delta \mathrm{C}^{*}(\tau)$ is equivalent to $\mathrm{C}_{\mathrm{ANT}}$ disregarding the disequilibrium term in equation 3. 


\section{TABLES.}

Table 1. Organic $(\mathrm{Co})$ and inorganic $(\mathrm{Ci})$ carbon fluxes at different depth layers measured by Martin et al. (1993) in sediment traps deployed at the NABE site and results from the 1D model proposed in this work. "Mean" refers to the mean profile of Apparent Oxygen Utilisation (AOU) and dissolution of calcium carbonate $(\Delta \mathrm{Ci})$ using data from the OacesNAtlIIB-93. $\Delta \mathrm{Ci}$ is calculated as: a) $\Delta \mathrm{Ci}=\mathrm{IOR} \cdot \mathrm{AOU} / \mathrm{R}_{\mathrm{C}}$, where IOR is calculated from equation 12 and b) $\Delta \mathrm{Ci}=1 / 2 \cdot\left(\mathrm{TA}^{\mathrm{T}} \mathrm{TA}{ }^{0}\right.$ + AOU $/ \mathrm{R}_{\mathrm{N}}$ ), using TA ${ }^{0}$ from GSS'96. $\mathrm{R}_{\mathrm{C}}$ and $\mathrm{R}_{\mathrm{N}}$ are stoichiometric coefficients from Anderson and Sarmiento (1994). $\mathrm{v}_{\mathrm{z}}$ stands for the water turnover velocity in $\mathrm{m} \cdot \mathrm{d}^{-1}$. Depth is expressed in $\mathrm{km}$, AOU and $\Delta \mathrm{Ci}$ in $\mu \mathrm{mol} \cdot \mathrm{kg}^{-1}$ and the $\mathrm{Co}$ and $\mathrm{Ci}$ fluxes in $\mathrm{mol} \cdot \mathrm{m}^{-2} \cdot \mathrm{d}^{-1}$.

\begin{tabular}{||c||c|c|c|c||c|c||c|c|c||}
\hline Source & Fitted & Mean & Mean $^{\mathrm{a}}$ & Mean $^{\mathrm{b}}$ & Traps & Traps & Model & Model $^{\mathrm{a}}$ & Model $^{\mathrm{b}}$ \\
\hline \hline Depth & $\mathrm{v}_{\mathrm{z}}$ & AOU & $\Delta \mathrm{Ci}$ & $\Delta \mathrm{Ci}$ & Co flux & Ci flux & Co flux & Ci flux & Ci flux \\
\hline \hline 0.00 & & & & & 14.35 & 2.44 & 14.35 & 2.44 & 2.44 \\
\hline 0.15 & 0.35 & 11.4 & 0.6 & -2.9 & 10.50 & 1.97 & 11.09 & 2.16 & 1.91 \\
\hline 0.30 & 0.29 & 31.1 & 2.3 & -2.1 & 4.83 & 1.57 & 6.75 & 1.63 & 1.67 \\
\hline 0.50 & 0.25 & 48.1 & 4.2 & -1.5 & 3.25 & 1.22 & 3.65 & 1.13 & 1.54 \\
\hline 0.75 & 0.22 & 58.3 & 5.3 & -1.5 & 3.00 & 1.23 & 2.02 & 0.87 & 1.54 \\
\hline 1.00 & 0.20 & 60.6 & 5.3 & -1.9 & 1.62 & 0.93 & 1.69 & 0.85 & 1.62 \\
\hline 1.50 & 0.18 & 63.4 & 5.6 & -2.5 & 1.08 & 0.77 & 1.33 & 0.81 & 1.73 \\
\hline 2.00 & 0.16 & 68.0 & 7.7 & -1.5 & 1.04 & 0.49 & 0.79 & 0.45 & 1.55 \\
\hline
\end{tabular}


Table 2. Mean values of pressure (in $\mathrm{db}$ ), $\mathrm{CFC}_{11}$ age (in years), air-sea disequilibrium in terms of carbon $\left(\Delta \mathrm{C}_{\text {Tdis }}\right.$ in $\left.\mu \mathrm{mol} \cdot \mathrm{kg}^{-1}\right)$ and $\mathrm{pCO}_{2}\left(\Delta \mathrm{pCO}_{2 \text { dis }}\right.$ in $\left.\mu \mathrm{atm}\right)$ on potential density surfaces along the OacesNAtlIIB-93. SDM stands for the standard deviation weighted by the number of determinations (n). $\Delta C^{*}(\tau)$ is calculated from equation $4, \mathrm{C}_{\mathrm{ANT}}$ GSS'96 (in $\mu \mathrm{mol} \cdot \mathrm{kg}^{-1}$ ) stands for the calculation of the anthropogenic carbon according to Gruber et al. (1996), i.e., $\mathrm{C}_{\mathrm{ANT}}=\Delta \mathrm{C}^{*}(\tau)$ $\Delta \mathrm{C}_{\text {Tdis }}$

\begin{tabular}{|c|c|c|c|c|c|c|c|}
\hline $\begin{array}{l}\text { Density } \\
\left(\mathrm{kg} \cdot \mathrm{m}^{-3}\right)\end{array}$ & $\begin{array}{l}\text { Press. } \\
\text { (db) }\end{array}$ & $\begin{array}{c}\mathrm{CFC}_{11} \\
\text { age }\end{array}$ & $\Delta \mathrm{C}_{\mathrm{Tdis}} \pm \mathrm{SDM}$ (n) & $\Delta \mathrm{pCO}_{2 \text { dis }} \pm \mathrm{SDM}$ & $\Delta C^{*}(\tau)$ & $\begin{array}{c}\mathrm{C}_{\mathrm{ANT}} \\
\text { GSS'96 }\end{array}$ & Method \\
\hline \multicolumn{8}{|c|}{$\sigma_{\theta}$ Surfaces } \\
\hline $26.9-27$ & 194 & 6 & $-3.7 \pm 1.7$ & $-6.3 \pm 2.9$ & 42 & 46 & Eq.3.7 \\
\hline $27-27.1$ & 239 & 6 & $0.0 \pm 0.7$ & $0.1 \pm 1.3$ & 45 & 45 & Eq.3.7 \\
\hline $27.1-27.2$ & 304 & 7 & $3.3 \pm 0.5$ & $6.2 \pm 0.9$ & 46 & 43 & Eq.3.7 \\
\hline $27.2-27.3$ & 420 & 10 & $4.9 \pm 0.5(31)$ & $9.4 \pm 1.0$ & 44 & 39 & Eq.3.7 \\
\hline $27.3-27.4$ & 458 & 13 & $2.8 \pm 0.7(30)$ & $5.6 \pm 1.3$ & 40 & 37 & Eq.3.7 \\
\hline \multicolumn{8}{|c|}{$\sigma_{\theta^{-}} \sigma_{2}$ Surfaces } \\
\hline $27.4-36.5$ & 573 & 13 & $3.2 \pm 0.6 \quad(51)$ & $6.7 \pm 1.3$ & 39 & 36 & Eq.3.7 \\
\hline \multicolumn{8}{|c|}{$\sigma_{2}$ Surfaces } \\
\hline $36.5-36.6$ & 801 & 17 & $-0.4 \pm 0.6(30)$ & $-0.5 \pm 1.2$ & 32 & 33 & Eq.3.7 \\
\hline $36.6-36.7$ & 892 & 18 & $-3.6 \pm 0.5(19)$ & $-6.7 \pm 0.9$ & 27 & 31 & Eq.3.7 \\
\hline $36.7-36.8$ & 1087 & 20 & $-4.7 \pm 0.4(28)$ & $-8.6 \pm 0.7$ & 25 & 29 & Eq.3.7 \\
\hline $36.8-36.9$ & 1372 & 21 & $-4.9 \pm 0.4(39)$ & $-9.2 \pm 0.8$ & 23 & 28 & Eq.3.7 \\
\hline $36.9-37$ & 1939 & 25 & $-7.4 \pm 0.5(53)$ & $-13.7 \pm 0.9$ & 18 & 26 & Eq.3.7 \\
\hline \multicolumn{8}{|c|}{$\sigma_{2}-\sigma_{4}$ Surfaces } \\
\hline $37-45.81$ & 2422 & 32 & $-12.9 \pm 0.9(10)$ & $-23.2 \pm 1.6$ & 10 & 23 & Eq.3.7 \\
\hline \multicolumn{8}{|c|}{$\sigma_{4}$ Surfaces } \\
\hline $45.81-45.88$ & 2715 & 33 & $3.0 \pm 0.9 \quad(8)$ & $4.9 \pm 1.4$ & 3 & 0 & Eq.3.8 \\
\hline $45.88-45.95$ & 3925 & 39 & $3.8 \pm 0.5 \quad(36)$ & $6.3 \pm 0.8$ & 4 & 0 & Eq.3.8 \\
\hline
\end{tabular}


Table 3. Estimations of the air-sea disequilibrium in terms of carbon $\left(\Delta \mathrm{C}_{\mathrm{Tdis}}\right)$ and $\mathrm{pCO}_{2}\left(\Delta \mathrm{pCO}_{2 \mathrm{dis}}\right)$ from total inorganic carbon $\left(\mathrm{C}_{\mathrm{T}}\right)$, partial pressure of $\mathrm{CO}_{2}$ $\left(\mathrm{pCO}_{2}\right)$, alkalinity $\left(\mathrm{TA}^{0}\right)$ and Apparent Oxygen Utilization (AOU) data collected by different authors. $\Delta \mathrm{C}_{\text {Tdis }}$ (equation 2 ) is calculated as the difference between preformed total inorganic carbon $\left(\mathrm{C}_{\mathrm{T}}^{0}(\tau)\right.$, equation 1$)$ and that in equilibrium with the corresponding atmospheric $\mathrm{CO}_{2}\left(\mathrm{C}_{\mathrm{T}}{ }^{\text {eq }}(\tau)\right)$. Correspondingly, $\Delta \mathrm{pCO}_{2 \text { dis }}$ is the difference between preformed $\mathrm{pCO}_{2}\left(\mathrm{pCO}_{2}{ }^{0 \tau}\right)$ and that in the atmosphere $\left(\mathrm{pCO}_{2}{ }^{\text {air }}\right)$. CARINA stands for the CARbon dioxide In the North Atlantic ocean program and MLD for Mixed Layer Depth. ${ }^{*}$ stands for measured and ${ }^{+}$for calculated $\mathrm{CO}_{2}$ initial variables. All the $\mathrm{C}_{\mathrm{T}}$ variables, $\mathrm{TA}^{0}$ and $\mathrm{AOU}$ are in $\mu \mathrm{mol} \cdot \mathrm{kg}^{-1}, \mathrm{pCO}_{2}$ variables are in $\mu \mathrm{atm}$.

\begin{tabular}{|c|c|c|c|c|c|c|c|c|c|c|c|c|c|c|}
\hline \multicolumn{2}{|c|}{ Area / Time } & $\sigma_{\theta} / \sigma_{2}$ & $\theta / \mathrm{S}$ & $\mathrm{AOU}$ & $\mathrm{TA}^{0}$ & $\mathrm{C}_{\mathrm{T}}$ & $\mathrm{pCO}_{2}$ & $\mathrm{C}_{\mathrm{T}}^{0}(\tau)$ & $\mathrm{C}_{\mathrm{T}}^{\mathrm{eq}}(\tau)$ & $\Delta \mathrm{C}_{\text {Tdis }}$ & $\mathrm{pCO}_{2}{ }^{0 \tau}$ & $\mathrm{pCO}_{2}^{\text {air }}$ & $\Delta \mathrm{pCO}_{2 \text { dis }}$ & $\begin{array}{l}\text { Data source and } \\
\text { characteristics }\end{array}$ \\
\hline \multicolumn{2}{|l|}{ Irminger Sea. } & $27.59 / 36.61$ & $4.96 / 35.08$ & 12.0 & $2301^{+}$ & $2122^{*}$ & $360^{*}$ & 2114 & 2114 & 0.1 & 345 & 344 & 0.2 & \multirow{3}{*}{$\begin{array}{l}\text { Peng et al. (1987) } \\
\text { Data with MLD }>300 \mathrm{~m}\end{array}$} \\
\hline \multirow{2}{*}{\multicolumn{2}{|c|}{ March 1983-85 }} & $27.67 / 36.72$ & $5.52 / 35.08$ & 13.0 & $2302^{+}$ & $2130^{*}$ & $364^{*}$ & 2121 & 2122 & -0.7 & 347 & 348 & -1.3 & \\
\hline & & $27.74 / 36.81$ & $6.28 / 35.09$ & -7.0 & $2283^{+}$ & $2101^{*}$ & $329^{*}$ & 2106 & 2108 & -2.0 & 337 & 341 & -3.4 & \\
\hline \multirow{6}{*}{\multicolumn{2}{|c|}{$\begin{array}{l}\text { Eastern North } \\
\text { Atlantic, } 30^{\circ}-60^{\circ} \mathrm{N} \\
\text { along } 20^{\circ} \mathrm{W} \text {. } \\
\text { Summer } 1996 .\end{array}$}} & $26.95 / 35.67$ & $13.9 / 35.96$ & 4.9 & $2359^{*}$ & $2105^{*}$ & $353^{+}$ & 2102 & 2106 & -4.7 & 355 & 355 & -8.4 & \multirow{6}{*}{$\begin{array}{l}\text { Körtzinger et al. (2001) } \\
\text { Isopycnal analysis in } \\
\text { the Eastern North } \\
\text { Atlantic. }\end{array}$} \\
\hline & & $27.00 / 35.74$ & $13.3 / 35.86$ & 5.0 & $2354^{*}$ & $2109^{*}$ & $358^{+}$ & 2106 & 2108 & -2.3 & 355 & 355 & -4.1 & \\
\hline & & $27.05 / 35.82$ & $12.5 / 35.72$ & 5.1 & $2347^{*}$ & $2110^{*}$ & $357^{+}$ & 2106 & 2109 & -2.6 & 356 & 356 & -4.9 & \\
\hline & & $27.10 / 35.89$ & $11.8 / 35.61$ & 5.2 & $2341^{*}$ & $2116^{*}$ & $366^{+}$ & 2112 & 2111 & 1.8 & 356 & 356 & 3.4 & \\
\hline & & $27.20 / 36.06$ & $10 / 35.32$ & 5.4 & $2327^{*}$ & $2117^{*}$ & $362^{+}$ & 2113 & 2114 & -0.7 & 356 & 356 & -1.4 & \\
\hline & & $27.30 / 36.20$ & $8.9 / 35.21$ & 5.5 & $2322^{*}$ & $2124^{*}$ & $368^{+}$ & 2120 & 2118 & 1.9 & 357 & 357 & 3.9 & \\
\hline \multirow{2}{*}{$\begin{array}{l}\text { Labrador } \\
\text { Sea }(\mathrm{n}=127) \\
\text { Summer } 1996\end{array}$} & Mean & $27.76 / 36.92$ & $3.06 / 34.85$ & 25.1 & $2298^{*}$ & $2152^{*}$ & $383^{+}$ & 2134 & 2136 & -1.3 & 343 & 345 & -1.5 & \multirow{2}{*}{$\begin{array}{l}\text { CARINA data base. } \\
\text { Mintrop/Körtzinger }\end{array}$} \\
\hline & STD & 0.02 & $0.13 / 0.01$ & 3 & 2 & 2 & 3 & 2 & 2 & 3.8 & 3 & 1 & 6.9 & \\
\hline
\end{tabular}




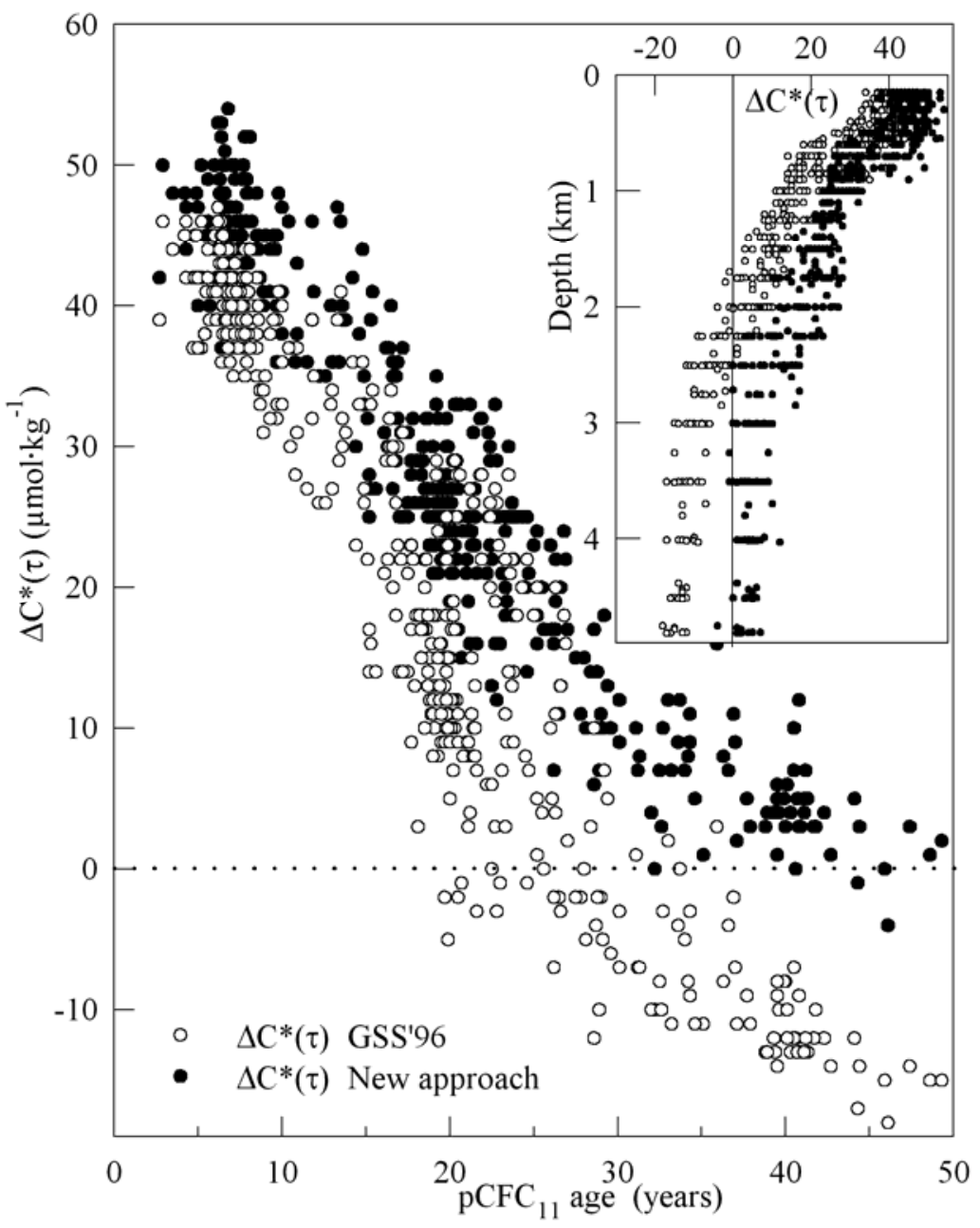

